\title{
Information seeking and information sharing behaviour in the climate change community of practice in the Pacific Implications for models of library services in scientific and technical libraries
}

By

Peter Warren Murgatroyd

Submitted to the School of Information Management, Victoria University of Wellington in partial fulfilment of the requirements for the degree of Master of Library and Information Studies

June 2011 


\section{Acknowledgements}

I would like to thank my colleagues in the region for sharing their time, wisdom and passion. It has been a great privilege to have worked with you. In particular I would like to thank Miraneta Williams-Hazelman and Eleanor Kleiber for encouraging and supporting me to complete my MLIS and my colleagues at SPREP and the University of the South Pacific for their generosity and friendship.

Thanks to my supervisor, Philip Calvert, for his ideas and input in refining the focus of my research and for planting the seed for my Pacific journey during his lectures in International and Comparative Librarianship two decades earlier.

Special thanks to my family, who have supported and encouraged me to complete my studies even when it meant dad having his head in books or his laptop during holidays and weekends. I love you to bits. 


\title{
Disclaimer
}

\section{VICTORIA UNIVERSITY OF WELLINGTON}

\author{
School of Information Management
}

Master of Information Studies

IMPORTANT DISCLAIMER

with respect to MLIS Research Project (INFO 580)

'Information seeking and information sharing behaviour in the climate change community of practice in the Pacific: implications for models of library services in scientific and technical libraries'

(hereafter referred to as 'The MLIS Research Project')

\author{
being undertaken by
}

Peter Murgatroyd

In partial fulfilment of the requirements of the degree of Master of Library and Information Studies, School of Information Management, Victoria University of Wellington.

Topic Commencement: November 2010

- Victoria University of Wellington and its Council, its members, staff, employees, students and agents undertake no duty of care in contract, tort, or otherwise, to users (whether direct or indirect) to the MLIS Research Project and make no warranties or representations of any kind whatsoever in relation to any of its contents.

- The MLIS Research Project is only made available on the basis that all users of it, whether direct or indirect, must take appropriate legal or other expert advice in relation to their own circumstances and must rely solely on their own judgement and such legal or other expert advice.

- Under no circumstances will Victoria University of Wellington and its Council, its members, staff, employees, students or agents be liable in any way whatsoever, whether in contract, tort (including negligence), for breach of any statutory or regulatory duty (to the fullest extent permissible by law), or otherwise, to any user (whether direct or indirect) of the MLIS Research Project for any loss or damage whatsoever arising directly or indirectly as a result of the use in any way of the MLIS Research Project.

- Each exclusion in the clauses of this disclaimer and each protection given by it is to be construed as a separate exclusion applying and surviving even if for any reason any of the exclusions or protections are held inapplicable in any circumstance. 


\section{Contents}

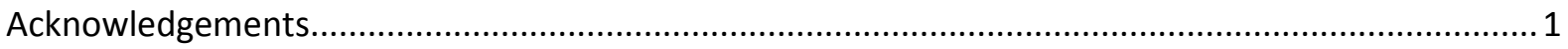

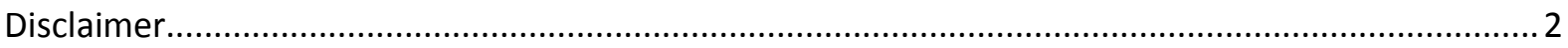

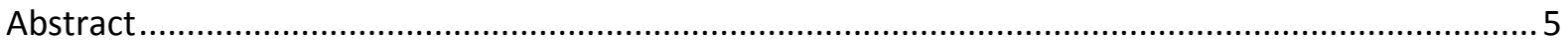

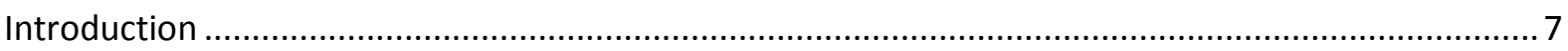

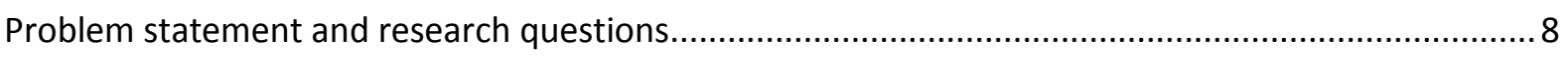

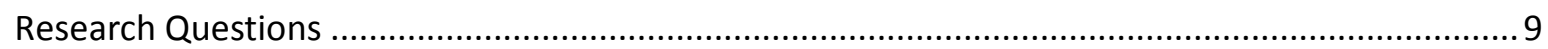

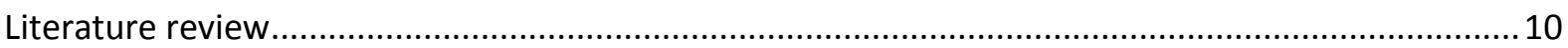

The status of scientific and technical libraries in the Pacific ..................................................... 10

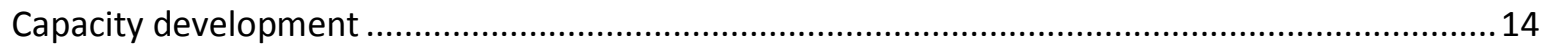

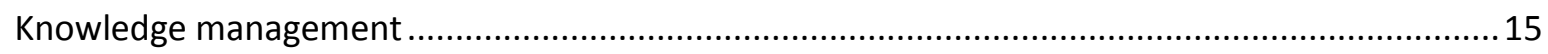

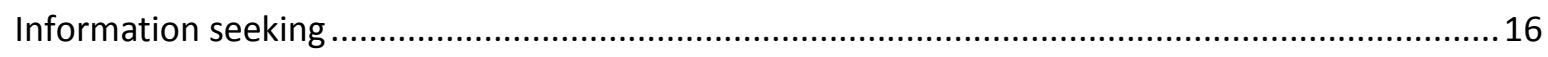

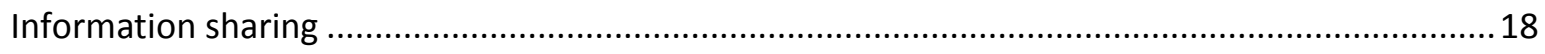

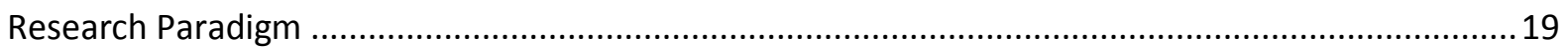

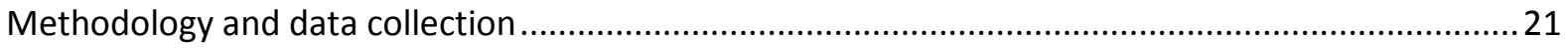

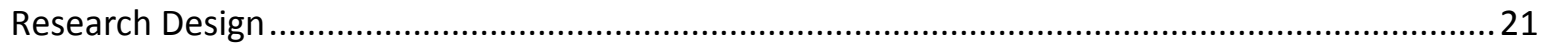

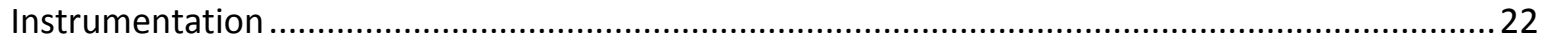

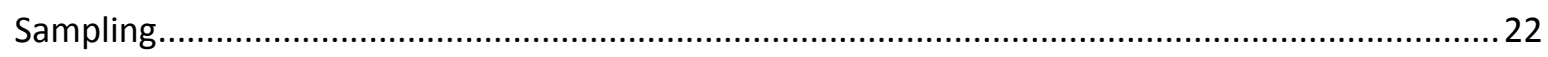

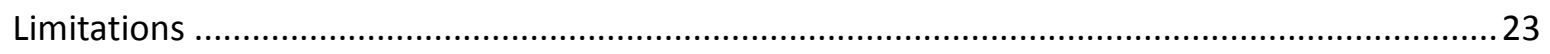

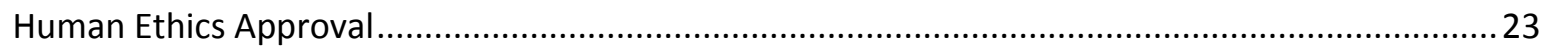

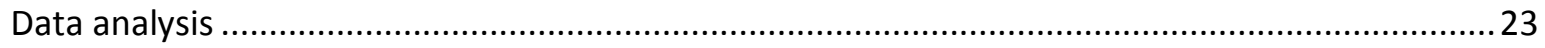

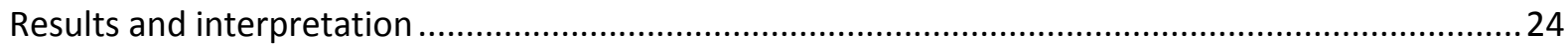




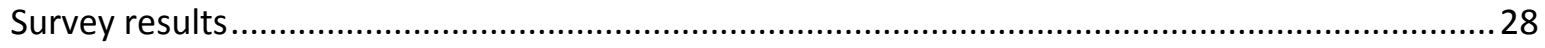

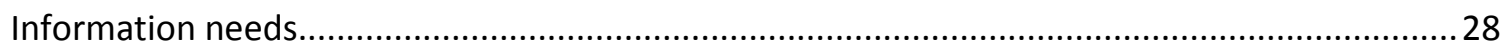

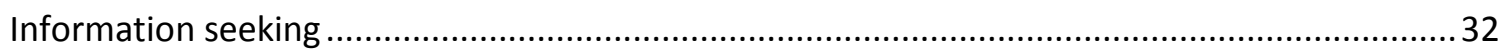

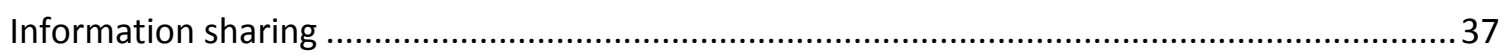

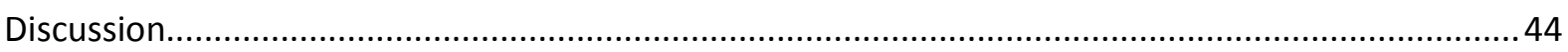

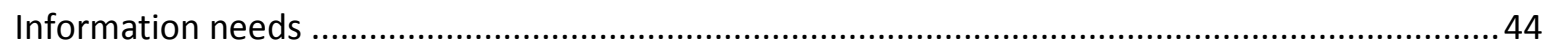

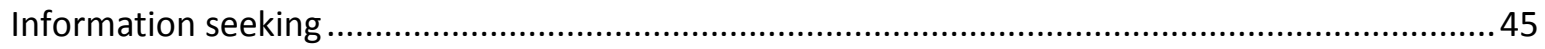

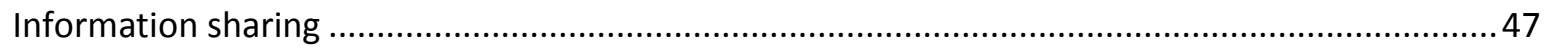

Conclusion: Implications for libraries and models of capacity development in the Pacific ................50

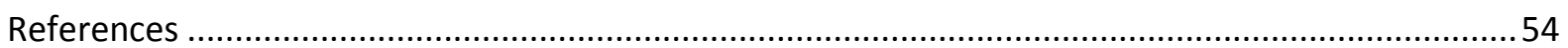

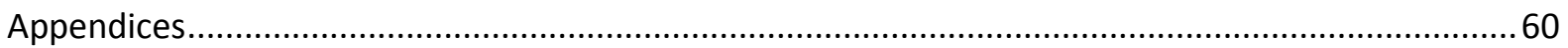

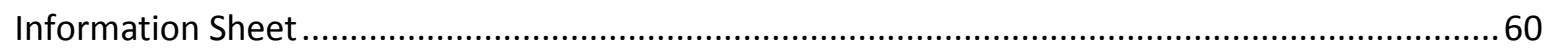

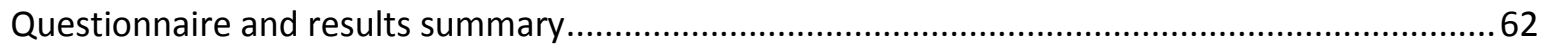




\section{Abstract}

Focusing on one 'community of practice' - climate change - this research examines the extent to which traditional concepts of library services in scientific and technical libraries (and consequently models of library development) in the Pacific region are aligned to the identified information needs and dominant modes of information seeking and information sharing behaviour of stakeholders. A quantitative survey research methodology was utilized to collect primary data from a census of the identified 'community of practice' in order to determine dominant behaviours, perceptions and attitudes amongst respondents towards information seeking and information sharing. The prominence of informal networks for communication and information exchange and the value still ascribed to face-to-face encounters and the development of personal relationships was a dominant theme as was the reliance on internet technologies to acquire and share information. Libraries, at both the regional and national level, were viewed as less useful than alternative pathways for both information seeking and information sharing. A detailed literature review of capacity building initiatives in libraries in the region over the preceding two decades confirms that capacity across the region remains low and the perception and status of libraries within the government sector in the region is poor. Acknowledging the rapid shifts in the information landscape towards electronic access to information and the proliferation of web 2.0 pathways for communication and information, it is argued that if capacity in library and information management in the region is to be strengthened there needs to be a re-evaluation of the role of the library not only in relation to the need for alignment with the goals and objectives of the host organisation but also in light of attitudes towards information and information seeking and information sharing behaviour. Consultations within the climate change community during 2011 have highlighted the clear need to improve access to information and data both nationally and regionally in the Pacific and the value of establishing a region-wide portal mechanism for collating and disseminating climate-related 
information. Within this context Pacific libraries within the government sector and the regional level must redefine their role and the services that they offer if they are to be valued and seen as useful and relevant to stakeholders.

Keywords: $\quad$ libraries; knowledge management; capacity building; Pacific islands; climate change 


\section{Introduction}

For more than two decades, Pacific regional organisations have engaged in sector based projects to build capacity in library and information management within government departments across the region. Capacity building projects in the agricultural, fisheries and environment sectors have focused primarily on the provision of equipment and library management software and localized training in organising, cataloguing and managing hardcopy library collections within government departments. At the regional organisation level these initiatives have not been coordinated across sectors and have been implemented without the benefit of an overall regional strategy for capacity building. Sustainability of these initiatives has been problematic and capacity across the region remains low and the perception and status of libraries within the government sector in the region is poor. Libraries remain under-resourced and poorly utilized by stakeholders and government department library officers, where they are in place, are commonly without qualification and training and of low status within the organisational hierarchy (Mamtora, 2001; Walton and Erasito, 2003; Walton, 2006; Davies, 2007; Cohen and Vilmei, 2008). The model of capacity building followed by regional organisations has been primarily focused on individual capacity with little attention paid to institutional structures and processes and organisational context and culture in regards both information sharing and information seeking behaviour of individual stakeholders and the relationship between the services provided by the library and the goals and objectives of the organisation.

Arguably if capacity in library and information management at country level is to be strengthened there may need to be a re-evaluation of the role of the library not only in relation to the need for alignment with the goals and objectives of the host organisation but also in light of attitudes towards information and information sharing and information seeking behaviour. Moreover rapid shifts in 
the information landscape towards electronic access to information and the proliferation of web 2.0 pathways for communication and information sharing demands a revision of the place of traditional hardcopy library resources and their relevance in the government sector. Within this context any regional framework or strategy for capacity building needs to take a holistic approach - individual, institutional and contextual - and to align new models of library service provision with the goals and objectives of stakeholders and to offer services that are in harmony with new ways of sharing and seeking information.

\section{Problem statement and research questions}

The dominant problem explored is the extent to which traditional concepts of library services in scientific and technical libraries (and consequently models of library development) in the region are aligned to the identified information needs and dominant modes of information seeking and information sharing behaviour of stakeholders.

The focus of the research is upon one specific 'community of practice' - climate change. 'Climate change' has been identified by the Director General of the Pacific Islands Forum Secretariat as the single most critical issue addressing the Pacific currently. It is an issue that is being addressed at varying levels by the Pacific Islands Forum Secretariat, the Secretariat of the Pacific Community (SPC), SOPAC (Pacific geoscience agency) and the Secretariat of the Pacific Regional Environment Programme (SPREP) and is critical to a range of government sectors - including meteorology, environment, disaster management, agriculture and forestry, fisheries and public works. Stakeholders include high level government policy makers and advisers, technical staff managing and implementing projects and programmes across a range of sectors at national and regional level, scientists and researchers and civil society - NGO's and grassroots community interests. Timely 
access to current, accurate and relevant information is critical to stakeholders at both regional and national level across the Pacific.

An understanding of the concept of 'communities of practice'- defined more by the relationships between members than organisational structures and fixed roles - where information flows between members across institutional, geographical, and thematic boundaries is central to the research focusing on the 'climate change' community of practice. Communities of practice can be defined as "groups of people who share a concern, set of problems, mandate, or sense of purpose. Communities of practice complement existing structures by promoting collaboration, information exchange, and sharing of best practices across boundaries of time, distance, and organizational hierarchies" (http://www.qualishealth.org/qi/collaboratives/glossary.cfm).

How well are scientific and technical libraries at both the national and regional levels meeting this information need in this critical 'community of practice'? Are the models of library and library services that have predominated in the region during the last two decades perceived as being relevant and useful by stakeholders? Have new modes of information sharing and information seeking superseded the role traditionally occupied by an institutional library and indeed how well do we understand the information behaviour of stakeholders in the Pacific in the $21^{\text {st }}$ century.

\section{Research Questions}

Focussing on one 'community of practice' - climate change, key questions that this research seeks to answer include: 
How does information flow between stakeholders within this community of practice? What are the dominant information pathways?

How do these pathways differ between country and regional institutions?

What are the dominant information needs of stakeholders?

How are these information needs met? What are the predominant modes of information seeking behaviour?

What are the predominant attitudes towards information sharing? How is information shared? How do members of the climate change community of practice perceive the role of libraries and librarians at both regional and national level? Are they considered to be part of the climate change information network - or outside of it? Are library services seen as useful and relevant to them? Identifying one specific community of practice - climate change - as a key subgroup of stakeholders in the Pacific region, to examine to what extent libraries at country and regional level are aligned to their information needs and information seeking behaviours?

\section{Literature review}

\section{The status of scientific and technical libraries in the Pacific}

In 1983, the Fiji Library Association devoted an entire issue of the Fiji Library Association Journal (FLA Journal (10) Dec. 1983) to aspects of scientific and technological information in Fiji and the South Pacific. The contributions are invaluable insights into both library status and information needs as perceived by the profession at the time. Moreover subsequent contributions to the journal in later years serve as useful touchstones for the progress or lack thereof, in addressing these. It becomes 
clear when examining the descriptions of library status and information needs in the region over the period of this literature review that common themes emerge and that observations made in the early 1980 's remain valid and important today.

In an introductory article Howard (1983) highlighted the problems of inadequate resourcing and staffing of libraries and information centres in the region and emphasised the need for governments to take responsibility for addressing the issue and to support library development within their departments. She also identified a number of factors that limit access to critical scientific and technical information in the region. These include the identification and collection of relevant documents, inadequate bibliographic control of these documents, the shortage of qualified library staff in scientific and technical libraries, and the lack of government support for a strong centralized library service. An important factor in the slow development of libraries was the inaction, nonparticipation and low interest in the development of libraries (Williams, 1983).

Prasad (1983) concludes that the same problems are common to all govt. departments; citing a lack of trained staff, no career structure, a lack of clarity of the role of the library, low or non-existent library budget and a lack of suitable premises and equipment. Flores (1983) noted that the lack of standardization, inherent in a proliferation of separate sometimes competing systems, both added to costs and limited opportunities for information exchange.

A subsequent contribution to the journal in 1990 (Walton, 1990) reaffirmed Prasad's observations about agricultural information in the region. Walton noted that there was no shortage of information in the region but access to that information was the problem. He also noted that despite many attempts to remedy the situation the problem remained and cited a lack of trained staff, small 
or non-existent budgets, poor facilities and a low priority given to information in agricultural plans as the foremost barriers to change. Of these the situation in relation to staffing was the most critical issue, with staff - where they existed - being without appropriate levels of training and support.

A survey conducted in Fiji by Lal in 1992 (Lal, 1993) indicated that the great majority of personnel who worked in special libraries in Fiji had no professional qualifications and that furthermore only $10 \%$ of staff Fiji had any relevant vocational qualifications and that the majority of libraries operated on a shoe-string budget - many reliant on aid.

This low status and lack of recognition of the role and value of libraries is also highlighted by McDowell and Creech (1991) in relation to fisheries libraries in the region with the challenge of finding qualified staff to manage fisheries libraries again to the fore. She observed that the task of looking after the library was often assigned to the secretary or filing clerk who commonly would have little or no experience of libraries resulting in disorganised collections that were of little value or relevance to the department.

Fa'asili and Williams (1987) benchmark review of marine information needs in the region provided both the impetus and the framework for the development of the Pacific Islands Marine Resources Information System (PIMRIS). The study also detailed the status of library services in fisheries departments around the region at that time. In 1987 most fisheries departments did not have a library. Where there was a library, these were small, disorganized and uncatalogued. Documents and resources were commonly scattered throughout the department and not available from one central location. Not one of the departments surveyed had a trained librarian, or library officer, in place. When surveyed however, many departments identified the need to address these 
shortcomings in library services and the desirability of the establishment and training of designated library/information officers.

In 2001 the picture of poorly managed and under resourced department libraries was still prevalent. Mamtora (2001) described the situation as "distressing" that although libraries had been in existence for many years the shortcomings in relation to both a lack of resources and a lack of suitably trained and competent staff had largely remained the same.

The review of the status of the Pacific Islands Marine Resources Information System by the outgoing PIMRIS Coordinator in 2006 (Nelson, 2006) highlighted that sustainable capacity development in fisheries depts. in the region had been difficult to achieve and that the lack of suitably trained staff, and the low status of these staff, at government level continued to be the primary impediment to development of effective fisheries library and information services. The common perception that library and information management is simple clerical work that can be performed by any designated staff, coupled with the high turnover of staff in these positions are significant barriers to capacity development.

This lack of status of library/information officers and of marine information management generally at the country level was once more highlighted in a review undertaken by the IODE in 2007 (Davies, 2007) and again reaffirmed in a subsequent study by Reefbase Pacific a year later (Cohen and Vilmei, 2008). Lack of access to information, poorly organised and managed collections at local level and the lack of resources and trained staff to facilitate information access to stakeholders were as much in evidence in the region as they were 20 years previously. 
In 2003 a report of the evaluation of the Pacific Environment Information Network (Walton and Erasito, 2003) noted that staff assessments conducted in 1993 and 1994 detailing that the calibre and number of staff was low, were still valid. A lack of appropriately qualified and trained staff at the national level, and the lack of understanding at the institutional level of the role of the library, is common across all countries. It is interesting that the report notes that the predominant users of the libraries established under PEIN are school children. Moreover interviews conducted by the consultants revealed that not only did dept. staff not use the libraries, they were unaware of what the libraries contained.

A similar review in the agricultural sector in 2006 (Walton, 2006) concludes that progress in improving information management in the region was hampered by a lack of qualified, well trained and experienced staff. The staffing challenges are compounded by inadequate budgets, equipment and resources - a result, Walton concludes, of the low status and value attributed to the role of the library and information service in the organization. He also expresses the view that this situation will remain until such time as decision-makers become aware of the role effective information management can play in helping an institution achieve its objectives. Without such a change in perception there is, Walton argues, little likelihood of sustainability (Walton, 2006).

\section{Capacity development}

Within this context it is timely to briefly examine models of capacity development. Since the 1960 's capacity building has evolved from a focus on the individual - involving provision of training and skills, tools and equipment - to the organisation, whereby the focus was on organisational restructuring and systems of human resource, institutional and financial management and accountability, and finally to a model of institutional change and reform that encompasses not only the individual and the organisational issues but addresses institutional values, culture and both 
formal and informal systems of communication (UK Department for International Development). The lesson learned from decades of failed capacity building initiatives was that only when all three sets of elements - the individual, the organisation and the institutional environment - are aligned that sustainable capacity development is achievable. Arguably the model of library capacity development demonstrated in the Pacific over the last two decades reflects an over reliance on the 'individual' model of capacity development with only cursory attention to organisational systems and structures and almost no acknowledgement of the institutional contexts.

\section{Knowledge management}

The literature relating to knowledge management is extensive and complex and a thematic analysis of this field is beyond the scope of this study however it is useful to highlight issues that are particularly relevant. A series of information papers prepared by the Asian Development Bank to support capacity building in knowledge management in the Asia and Pacific region provide an excellent point of reference (Serrat, 2008; 2009; 2010).

Serrat (2008) usefully defines a number of characteristics of communities of practice stressing the importance of relationships between participants and the strong linkages between learning and action in the exchange of knowledge. He argues that harvesting of the knowledge that resides within a community of practice "hinges on trust and that is engendered by shared context" (Serrat, 2010). Full participation in a community of practice implies if not the actual breaking down of walls and barriers created by organisational silos - whereby an organisation lacks the desire or motivation to coordinate or communicate outside its defined boundaries - then at least the means or a process for this to happen. 


\section{Information seeking}

A review of managers' information seeking behaviour by de Alwis et al in 2006 traced a clear transformation in information seeking behaviour over the last three decades as the emergence and eventual dominance of ICTs within the workplace have transformed the information landscape. Studies conducted over the years reveal that managers place very heavy reliance on people as a source of information. However the tremendous impact on the workplace on the emergence and extensive use of ICTs offers managers a dynamic and interactive digital environment facilitating constant and instant connectivity via networked PC's/internet. Major studies on managers preference for information sources noted that two models predominated in the pre-1980's: the 'Cost-benefit' model whereby information sources were selected on the basis of expected benefits and the expected costs of using them and Zipf's 'law of least effort' model (Zipf, 1949) which implies that users select sources based on the least psychological and financial cost to gain access to the source while even sacrificing the quality of the information to be obtained. This model also relates to Mooer's Law which suggests that an information source or system may not be used if it is too troublesome to retrieve information from it. Accessibility and information richness were the focus of the 1980's with the main dimensions of source quality including accuracy, relevance, reliability and timeliness with low quality information being preferred over high if the information is timely and has a lower cost. In the new millennium users information seeking is dominated by use of the internet and consulting with colleagues outside the organisation mainly for information on unfamiliar areas and to keep up to date in fields of interest. Reliance on individuals outside the organisation is contrary to previous studies where colleagues inside the organisation are one of the top sources preferred.

A study of information seeking behaviour of scientists (Heminger et al. , 2007) indicated a dramatic shift away from hardcopy towards electronic access to information. Researchers built collections of 
electronic articles in the same way as they have collected hard copy materials in the past - even going so far as to organize and annotate them utilizing bibliographic databases. Numerous studies (Leckie et al, 1996) have shown that various types of professionals also perceive their own collections to be the most accessible even if the information is rather limited. Professionals prefer to seek information from their personal or office collections of known books and journals before going elsewhere. In a highly cited study on information seeking of professionals (Leckie et al, 1996), while both perceived quality and accessibility influence the choice of a first source, the latter stood out as the single and most important determinant of use.

Davy (2006) also argued that one of the primary predictors of a recipient's choice of sources is accessibility. Another finding that needs to be considered within the context of this research proposal is that the use of information technology to seek information depends heavily on the recipient perceiving that they the system will be useful and easy to use.

Research on information seeking in a digital environment by Nicholas et al. (2004) finds that users seldom penetrate a site to any depth, tend to visit a number of sites for any given information need and seldom return to sites they once visited. In the past, information seeking was seen to be the first step to creating knowledge. Now, the authors argue, it is a continuous process. This view is reflected also by Foster (2004) who argues that whilst studies of information seeking behaviour collectively since the 1960's have intimated that "information seeking exists within contexts, and is, a linear process consisting of stages and iterative activities" (Foster p.228), contemporary information seeking behaviour needs to be reinterpreted as a "dynamic, flowing holistic process". The role of incidental information acquisition as a component of an ecological model of information use (Williamson, 1998) is also of interest. The notion that people frequently "discover information" 
while monitoring their world in an attempt to keep their "internal models up to date" (Wilson, 1977, p.6) has profound implications for information behaviour in a networked environment. The model argues that people 'accidentally' find information as they engage in other activities. They find information incidentally that they think might be useful to resolve an information need.

Borgatti and Cross (2003) proposed a relational model of information seeking in which the probability of seeking information from another person is a function of knowing what that person knows; valuing what that person knows; being able to gain timely access to that persons thinking; and perceiving that seeking information from that person would not be too costly - costly in terms of either interpersonal risks or obligations incurred. Esteem and reputation and again trust are all cited as influences on the extent to which people will be forthcoming about their lack of knowledge.

\section{Information sharing}

Of direct relevance to the study of the Pacific climate change community of practice is Gharawi and Dawes (2010) study of information sharing in transnational government networks. They argued that the degree of alignment between the goals and interests of participating organisations represents a major influence of organisational context on the exchange process. Participants' perceptions of risks, costs and benefits are critical factors to the success of knowledge networks. Again, trust, is identified as playing a significant role in establishing, developing and maintaining interorganisational relationships and that organisational culture plays a significant role in the success of information sharing.

Park et al. (2010) suggest that usefulness, quality of information, and trust towards virtual communities influence information sharing and seeking activities. Trustworthiness of information 
sources is again noted as an important determinant of information usage. Dawes et al (2009) reaffirm that trust influences how culture, values and personal and organisational relations influence the process and outcomes of knowledge sharing. Common areas of agreement in relation to knowledge sharing noted by Dawes et al (2009) include privacy, confidentiality, security concerns, ambiguity about statutory authority to collect, share or release information; and different degrees of openness to public access. Moreover agencies that compete for budget, control of scarce resources or infrastructure, or dominance in a policy domain may be reluctant to reveal any knowledge assets that may reduce or threaten their discretion and autonomy or their ability to compete for power or influence. If the benefits of sharing are not clear, or if the exchange appears too one sided, the barriers go up.

Research by Ford and Staples (2006) relating to the 'perceived value of knowledge (PVK) [the value that the individual places on his/her knowledge] and by Thomas-Hunt et al (2003) on the impacts upon status or perceived status on knowledge sharing are also of interest. For high value knowledge, interpersonal factors are relevant for sharing (e.g. trust, interpersonal history, dislike) and that risk, confidentiality and ability to articulate the high value-knowledge are barriers (Ford and Staples, 2006). Social status - within organisations and within networks - could promote differential emphasis of shared, own and unique knowledge (Thomas-Hunt et al, 2003).

\section{Research Paradigm}

Whilst there would have been considerable value in following an interpretive qualitative approach to this research, exploring at depth the understandings, perceptions and behaviours of stakeholders at regional and country level across a range of sectors and across geographic locations, such an approach was not feasible given the limitations on time and resources that were available within the 
context of the INFO 580 project. Moreover following on from his role, over the past 3.5 years, as a Pacific regional coordinator of a capacity building project within the environment sector who has also liaised closely with a parallel project in the fisheries sector, the researcher has been in a position to be able to observe and engage closely with stakeholders in a range of institutional settings to develop a rich and 'thick' understanding of the information landscape. Close involvement with the climate change 'community of practice' as both an adviser on the development of a regional climate change portal and as a knowledge supplier have provided context for this research. Many of these observations, including input from partners and stakeholders, have been documented in internal project documents, travel reports and in outputs from national and regional workshops and meetings.

Thus building upon understandings gained through an interpretive stance the research follows a positivist framework and uses a quantitative methodology to elicit explicit and measurable data. The aforementioned collective knowledge base informed the development of a quantitative survey instrument that enabled the researcher to identify predominant perceptions, behaviours and patterns of information sharing and information seeking at both country and regional level and to identify and measure discrete variables that impact upon them. As per Neumann's definition of positivism (Neumann, 2003), efforts were made to build an objective representation of perceptions and behaviours from which conclusions and predictions could be drawn to inform a regional capacity building strategy. The manipulation and analysis of statistical data across a range of variables that was possible by taking a positivist quantitative approach has yielded fresh insights that will be useful in developing a revised model of capacity building and institutional strengthening of library and information services within the scientific and technical sectors at both the country and regional level. 
Arguably the basis for many of the variables explored have emerged from a long period of participation in the milieu in which the research is embedded allowing considerable opportunity for observation of behaviours and exploration of attitudes and perception in both formal and informal settings over a four year period.

The adoption of a neutral quantitative research instrument also allowed the researcher to remove the potential for researcher - subject bias that could otherwise have arisen if the researcher were to engage in a more qualitative approach.

\section{Methodology and data collection}

\section{Research Design}

Survey research methodology was utilized to collect primary data from a census of the target population in order to determine dominant behaviours, perceptions and attitudes amongst respondents towards information seeking and information sharing and to examine the interrelationships of identified variables (Tanner, 2002 p.89) and their impact upon patterns of behaviour.

A descriptive survey method was employed to describe the attitudes and behaviours of respondents and to draw from these findings implications for the development of a regional cross-sectoral strategy. Critical to the usefulness of this approach is the ability to identify precise measurable observations about respondents' individual behaviours and attitudes for the purpose of making generalisations about the wider population of identified stakeholders. 
The selection of survey questions was critical to the outcome and value of this research and as such extensive consultation and trialling/piloting of survey questions was an integral component of the survey instrument design. Close attention was paid to both the language used and question construction to avoid misunderstandings that could arise from English being a second language for many of the respondents.

Multiple indicator measures were used in order to gain a full understanding of the concepts under examination. Likert scales were used to measure intensity of feelings of respondents.

\section{Instrumentation}

A self-completion questionnaire comprising of mostly closed questions was developed utilising the Qualtrics online survey platform (http://www.qualtrics.com/) and the link for online completion of the survey disseminated to stakeholders via email, listserv and electronic social networks. Surveys were anonymous and assurances of confidentiality and privacy explicitly stated on the survey instrument. The survey was available to be completed from the online survey site for 21 days and reminders sent to the target population on a weekly basis to complete the survey.

\section{Sampling}

The survey link was sent to climate team members at SPREP, SPC and SOPAC as well as being disseminated via a regional climate change community of practice listserv. Targeted recipients, responsible for coordinating regional climate change projects were asked to re-circulate the survey amongst their regional colleagues and in-country project networks. Survey response was anticipated to be low so a combination of 'convenient' and 'snowball' sampling (Bryman, 2003 pp.183-184) was used to maximize use of existing information networks and to reach as many potential participants 
as possible.

\section{Survey data collection}

The survey data was compiled online by the Qualtrics online survey software and made available to the researcher via the Qualtrics portal for analysis as an aggregated data set with cross tabulation functionality between variables.

\section{Limitations}

The primary limitation of this study is that it focuses on one community of practice and does not attempt to include for analysis the behaviours and attitudes toward information sharing and seeking of all participants in the broader scientific and technical community in the Pacific such as fisheries, agriculture, forestry and the broader environment sector (including waste, and conservation).

\section{Human Ethics Approval}

Human Ethics Committee approval was sought and received to conduct the research.

\section{Data analysis}

The survey instrument was designed to measure a range of variables - nominal, ordinal, and interval/ ratio (Bryman, 2008 p.322). A rich nominal dataset was elicited detailing respondents age, gender, ethnicity, organizational role, and institutional setting. Cross tabulation of survey responses utilising this nominal dataset illuminated a number of unexpected differences between behaviours and attitudes of particular groups of respondents that arguably had been previously overlooked or little understood. 
Tests for validity (face and concurrent) of data were conducted.

\section{Results and interpretation}

\section{Response rate}

25 surveys were completed and submitted.

\section{Characteristics of respondents}

Respondents were asked to identify themselves by gender, age, institutional role, institutional affiliation, and ethnicity.

\section{Gender}

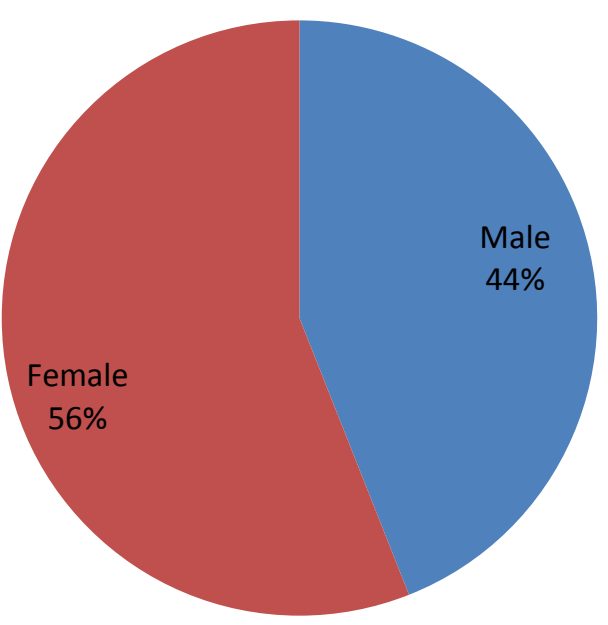



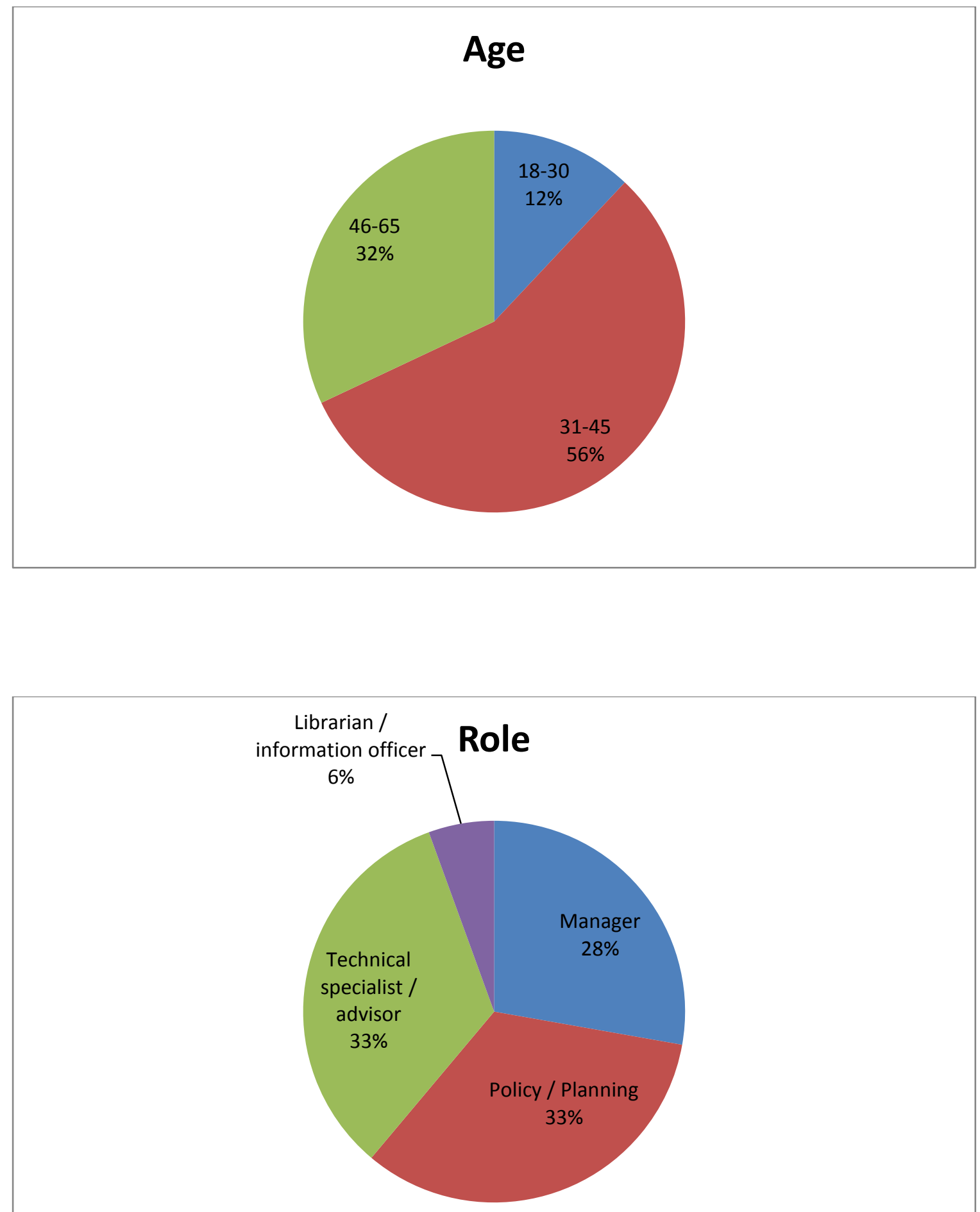

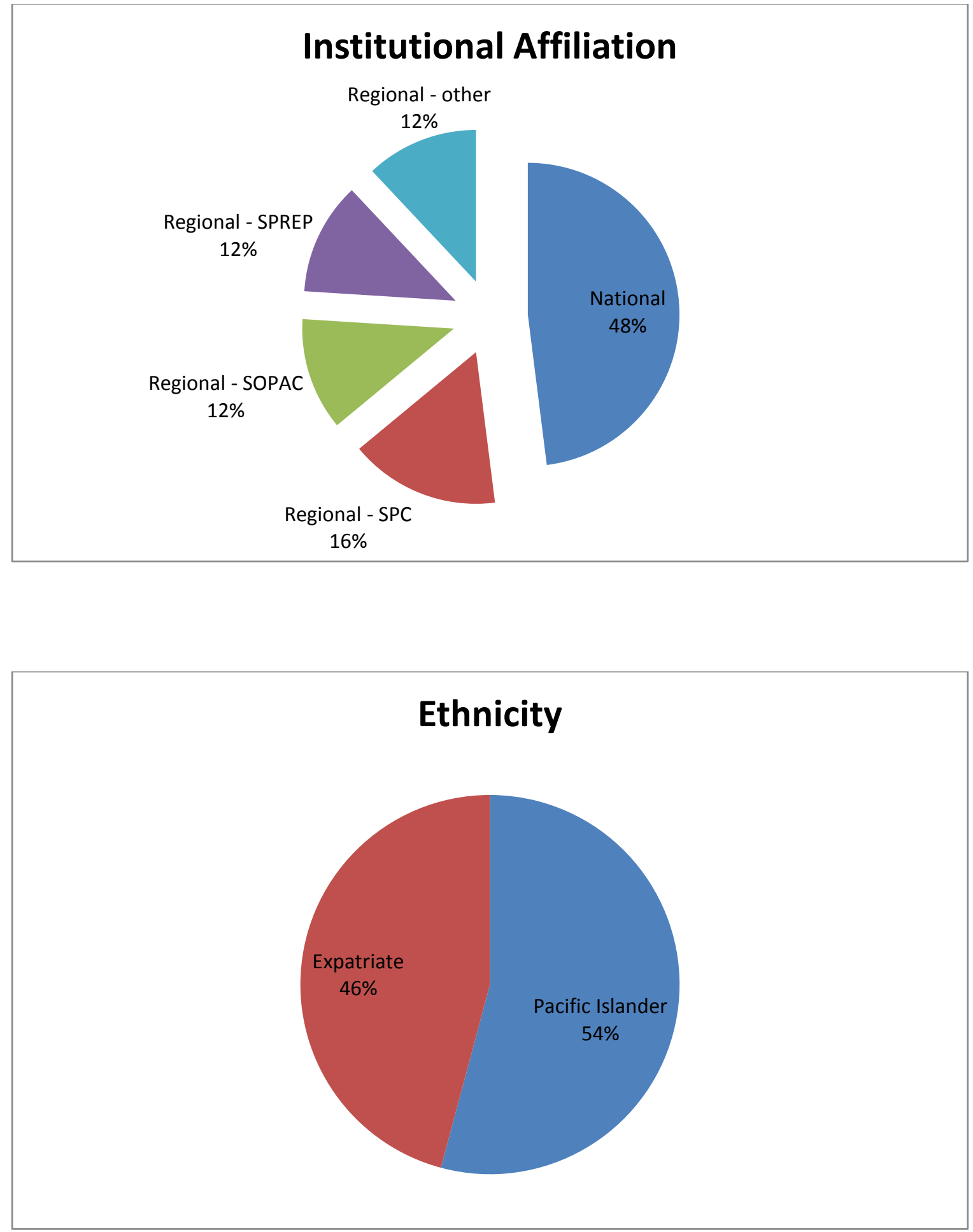

Cross tabulation of survey responses by respondent characteristics indicated that, for the most part, attitudes and behaviours were not strongly influenced by either gender, age or institutional role. However there were some very strong divergence in responses when analysed by institutional 
affiliation and ethnicity. The behaviours and attitudes towards information seeking and sharing and the perceptions of the value of libraries differ markedly between national and regional respondents and also between those respondents who identified themselves as expatriate and Pacific island respondents. 


\section{Survey results}

Information needs

What is the greatest information challenge that you face?

\begin{tabular}{|l|c|c|c|}
\hline \multirow{2}{*}{ Managing information overload } & Response & $\%$ \\
\cline { 2 - 4 } Finding relevant filtered information & & 9 & $36 \%$ \\
\cline { 2 - 4 } that meets your needs & & 4 & $16 \%$ \\
\hline Keeping current and up-to-date & & 2 & $8 \%$ \\
\hline Other (briefly describe in the space & & 1 & $4 \%$ \\
\hline provided below) & & 25 & $100 \%$ \\
\hline Total & & & \\
\hline
\end{tabular}

The two most prevalent challenges identified by respondents are how to manage information overload and how to find relevant filtered information that meets their needs. It is worth noting however that of those respondents who identified themselves as working at national level institutions, none indicated that information overload was their greatest challenge. The greatest challenge for $50 \%$ (3/6) of national respondents was finding relevant filtered information that meets their needs. In contrast 54\% (7/13) of regional respondents indicated that information overload was their greatest challenge and only $23 \%$ cited the need for filtered information (3/13) 


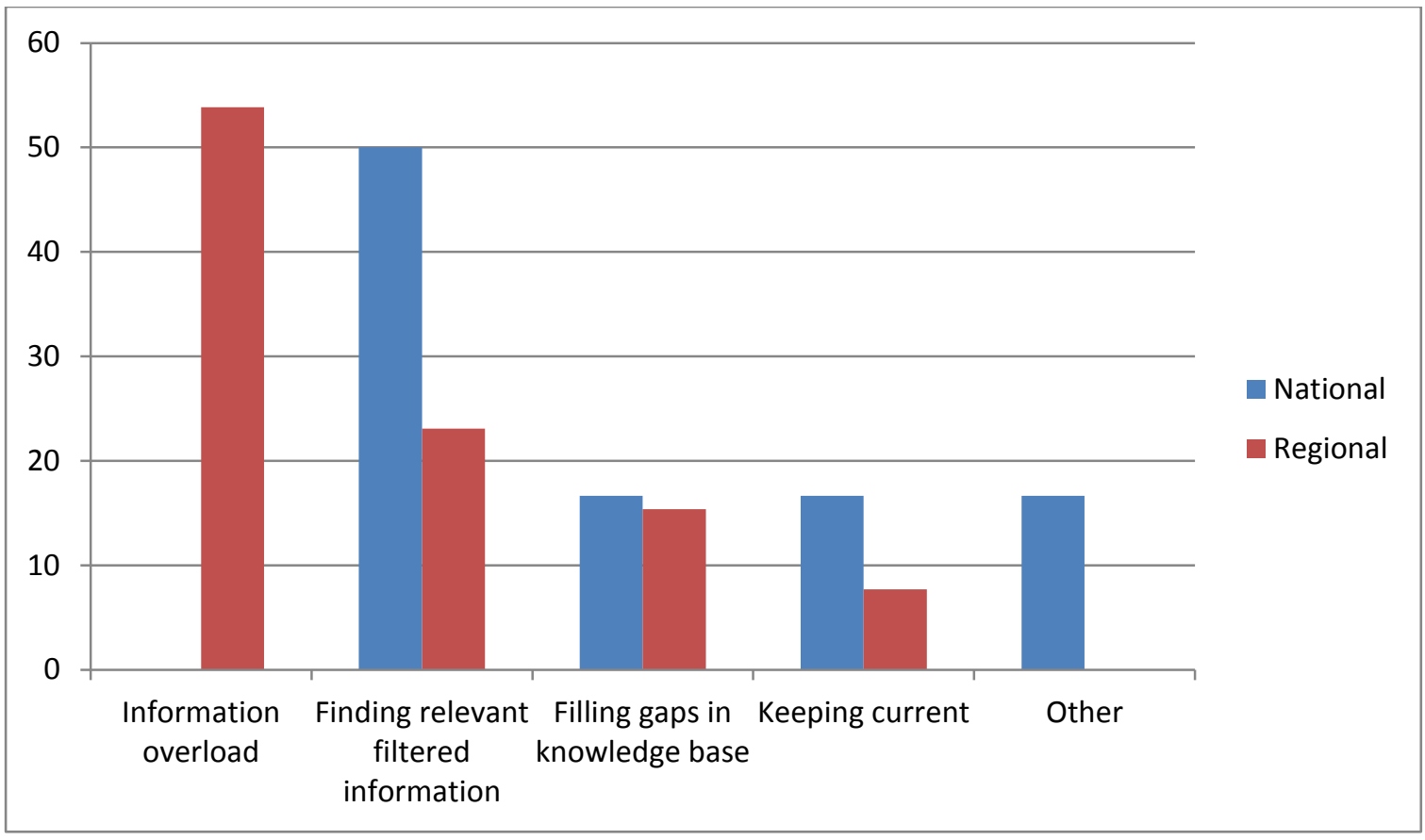




\begin{tabular}{|c|c|c|c|c|}
\hline & Essential & Desirable & $\begin{array}{c}\text { Not an important } \\
\text { consideration }\end{array}$ & Responses \\
\hline Information is available immediately & 15 & 10 & 0 & 25 \\
\hline $\begin{array}{l}\text { Information is available at low cost (or } \\
\text { free) }\end{array}$ & 15 & 8 & 2 & 25 \\
\hline Information is up-to-date & 18 & 7 & 0 & 25 \\
\hline $\begin{array}{l}\text { I am able to access and download the } \\
\text { information from my desktop }\end{array}$ & 17 & 8 & 0 & 25 \\
\hline $\begin{array}{l}\text { The information is authored or } \\
\text { endorsed by a recognised expert or } \\
\text { authority }\end{array}$ & 15 & 7 & 3 & 25 \\
\hline $\begin{array}{l}\text { The information is packaged and } \\
\text { filtered to meet my information need }\end{array}$ & 11 & 7 & 6 & 24 \\
\hline
\end{tabular}

At least $60 \%$ of respondents indicated that it was "essential" that information was available immediately, at low cost (or free), up-to-date, able to be accessed and downloaded from the desktop, and authored or endorsed by a recognized expert.

It is interesting to note that when cross tabulated by age, the requirement that information is endorsed by a recognized expert or authority, all respondents (8/8) in the age group 46-65 believed 
this to be essential, whereas only $42 \%(6 / 14)$ thought it was essential amongst those aged 32-45 and only $33 \%(1 / 3)$ of those aged 18-31. 
Information seeking

How often do you look for the following types of information?

\begin{tabular}{|c|c|c|c|c|c|c|c|c|}
\hline & Daily & $\begin{array}{c}2-3 \\
\text { Times } \\
a \\
\text { Week }\end{array}$ & $\begin{array}{c}\text { Once } \\
\text { a } \\
\text { Week }\end{array}$ & $\begin{array}{c}2-3 \\
\text { Times a } \\
\text { Month }\end{array}$ & $\begin{array}{l}\text { Once a } \\
\text { Month }\end{array}$ & $\begin{array}{l}\text { Less } \\
\text { than } \\
\text { Once a } \\
\text { Month }\end{array}$ & Never & Responses \\
\hline Scientific data & 3 & 5 & 7 & 3 & 4 & 1 & 1 & 24 \\
\hline $\begin{array}{l}\text { Published } \\
\text { reports }\end{array}$ & 3 & 8 & 6 & 2 & 3 & 2 & 1 & 25 \\
\hline $\begin{array}{l}\text { Unpublished } \\
\text { reports }\end{array}$ & 2 & 7 & 6 & 3 & 3 & 1 & 3 & 25 \\
\hline $\begin{array}{l}\text { Climate } \\
\text { change news }\end{array}$ & 12 & 6 & 4 & 0 & 1 & 2 & 0 & 25 \\
\hline $\begin{array}{l}\text { Conference / } \\
\text { Meeting / } \\
\text { Workshop } \\
\text { details }\end{array}$ & 3 & 5 & 5 & 2 & 8 & 1 & 1 & 25 \\
\hline $\begin{array}{l}\text { Funding } \\
\text { information }\end{array}$ & 4 & 2 & 4 & 3 & 5 & 5 & 2 & 25 \\
\hline Journal articles & 2 & 6 & 7 & 2 & 1 & 4 & 2 & 24 \\
\hline $\begin{array}{l}\text { Books about } \\
\text { climate change }\end{array}$ & 1 & 4 & 5 & 4 & 5 & 3 & 3 & 25 \\
\hline
\end{tabular}


The types of information most commonly sought on a regular basis (at least weekly) in descending order are climate change news (20/25), published reports (17/25), scientific data (15/24), unpublished reports (15/25), Journal articles (15/25), Conference / Meeting / Workshop details (13/25), Funding information (10/25), Books about climate change (10/25). Findings strongly illustrate the wide range of types of information that respondents seek and the high frequency of information seeking within the community.

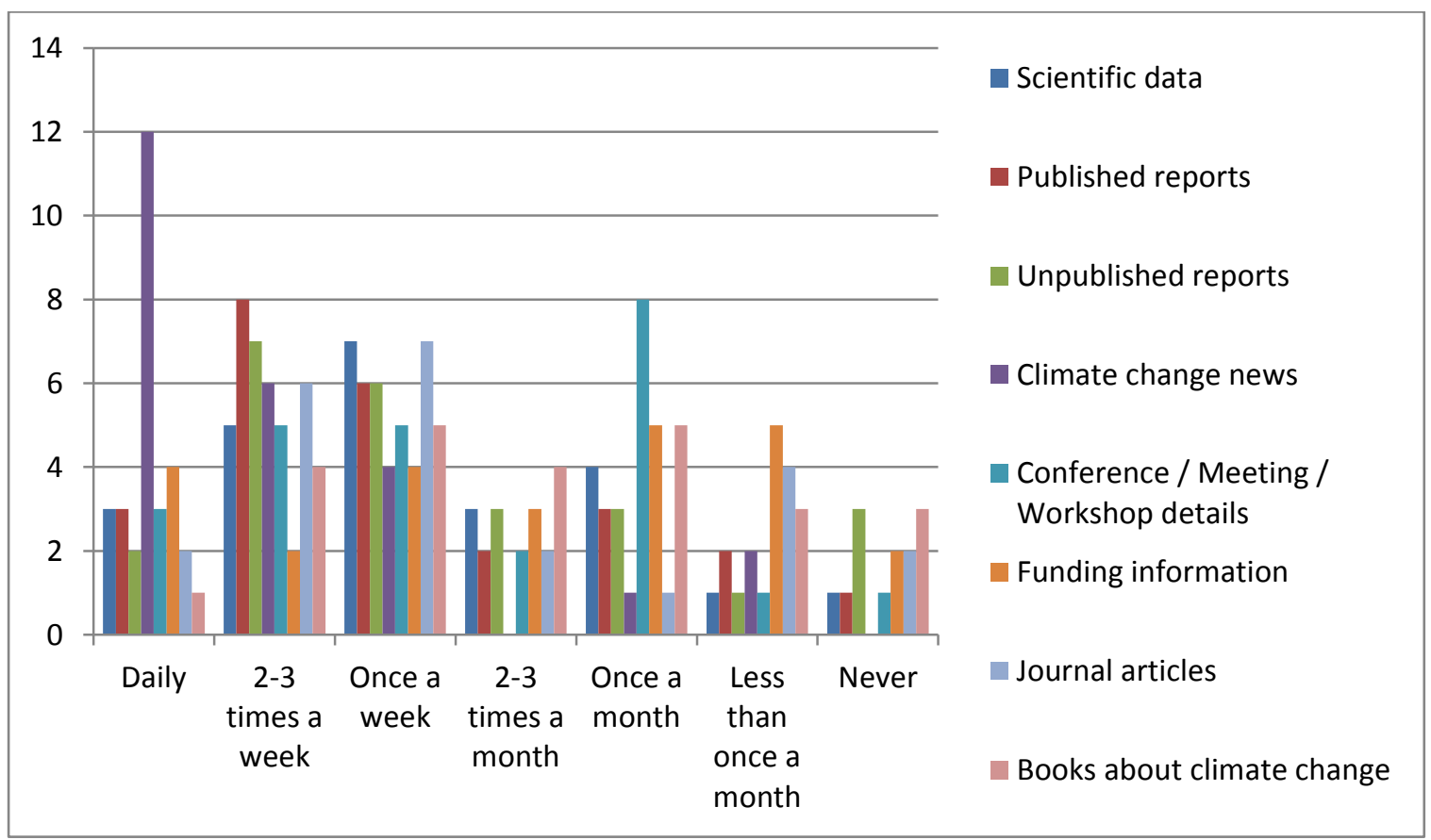


Rate the following information sources of climate change information in relation to their usefulness and relevance to your work

\begin{tabular}{|c|c|c|c|c|c|c|c|c|}
\hline & $\begin{array}{l}\text { Very } \\
\text { useful }\end{array}$ & Useful & $\begin{array}{c}\text { Somewhat } \\
\text { Useful }\end{array}$ & Neutral & $\begin{array}{l}\text { Somewhat } \\
\text { Useless }\end{array}$ & Useless & $\begin{array}{l}\text { Very } \\
\text { Useless }\end{array}$ & Responses \\
\hline $\begin{array}{l}\text { Internet } \\
\text { (via } \\
\text { Google } \\
\text { search) }\end{array}$ & 17 & 7 & 1 & 0 & 0 & 0 & 0 & 25 \\
\hline $\begin{array}{l}\text { Personal } \\
\text { collection }\end{array}$ & 11 & 10 & 2 & 1 & 1 & 0 & 0 & 25 \\
\hline Colleagues & 13 & 6 & 6 & 0 & 0 & 0 & 0 & 25 \\
\hline $\begin{array}{l}\text { National } \\
\text { network }\end{array}$ & 7 & 4 & 5 & 2 & 4 & 2 & 0 & 24 \\
\hline $\begin{array}{l}\text { Regional } \\
\text { network }\end{array}$ & 11 & 2 & 7 & 2 & 3 & 0 & 0 & 25 \\
\hline $\begin{array}{l}\text { Institution } \\
\text { al library - } \\
\text { local (e.g. } \\
\text { govt. } \\
\text { dept.) }\end{array}$ & 3 & 5 & 4 & 8 & 1 & 3 & 1 & 25 \\
\hline $\begin{array}{l}\text { Institution } \\
\text { al library - } \\
\text { regional }\end{array}$ & 8 & 5 & 4 & 6 & 1 & 1 & 0 & 25 \\
\hline
\end{tabular}




\begin{tabular}{|c|c|c|c|c|c|c|c|c|}
\hline $\begin{array}{l}\text { (e.g. } \\
\text { SPREP, } \\
\text { SPC, USP } \\
\text { etc.) }\end{array}$ & & & & & & & & \\
\hline The media & 5 & 8 & 6 & 2 & 4 & 0 & 0 & 25 \\
\hline
\end{tabular}

The most useful and relevant sources of climate change information amongst respondents were the internet (via a Google search), colleagues, and personal collections. Local institutional libraries were identified by respondents as the least useful and relevant sources of climate change information and regional institutional libraries received a comparable rating to national networks. When looking at which resources were considered of high value - either useful or very useful - the differences in attributions is very pronounced. In descending order the sources attributed high or very high usefulness and relevance are the internet (25/25), personal collections (21/25), colleagues (19/25), regional networks (13/25), regional institutional libraries (13/25), the media $(13 / 25)$, national networks (11/25), local institutional libraries (8/25).

Over $92 \%$ (12/13) of Pacific respondents rated their colleagues as being useful or very useful. This figure dropped to 54\% (6/11) for expatriates. Moreover 50\% (6/13) of Pacific respondents rated their national networks as being very useful and $69 \%$ thought their regional networks were very useful. The figures for expats are $0 \%(1 / 11)$ and $9 \%(1 / 11)$ respectively. $69 \%(9 / 13)$ of Pacific respondents thought that local institutional libraries were at least somewhat useful. This figure rises to $85 \%(11 / 13)$ for regional libraries. In contract the corresponding figures for expat respondents are $18 \%(2 / 11)$ and $55 \%(6 / 11)$. 
$83 \%(5 / 6)$ of respondents who described themselves as being from a national institution rated the regional institutional libraries as being useful or very useful. This figure drops to $54 \%(7 / 13)$ for respondents from regional organisations.

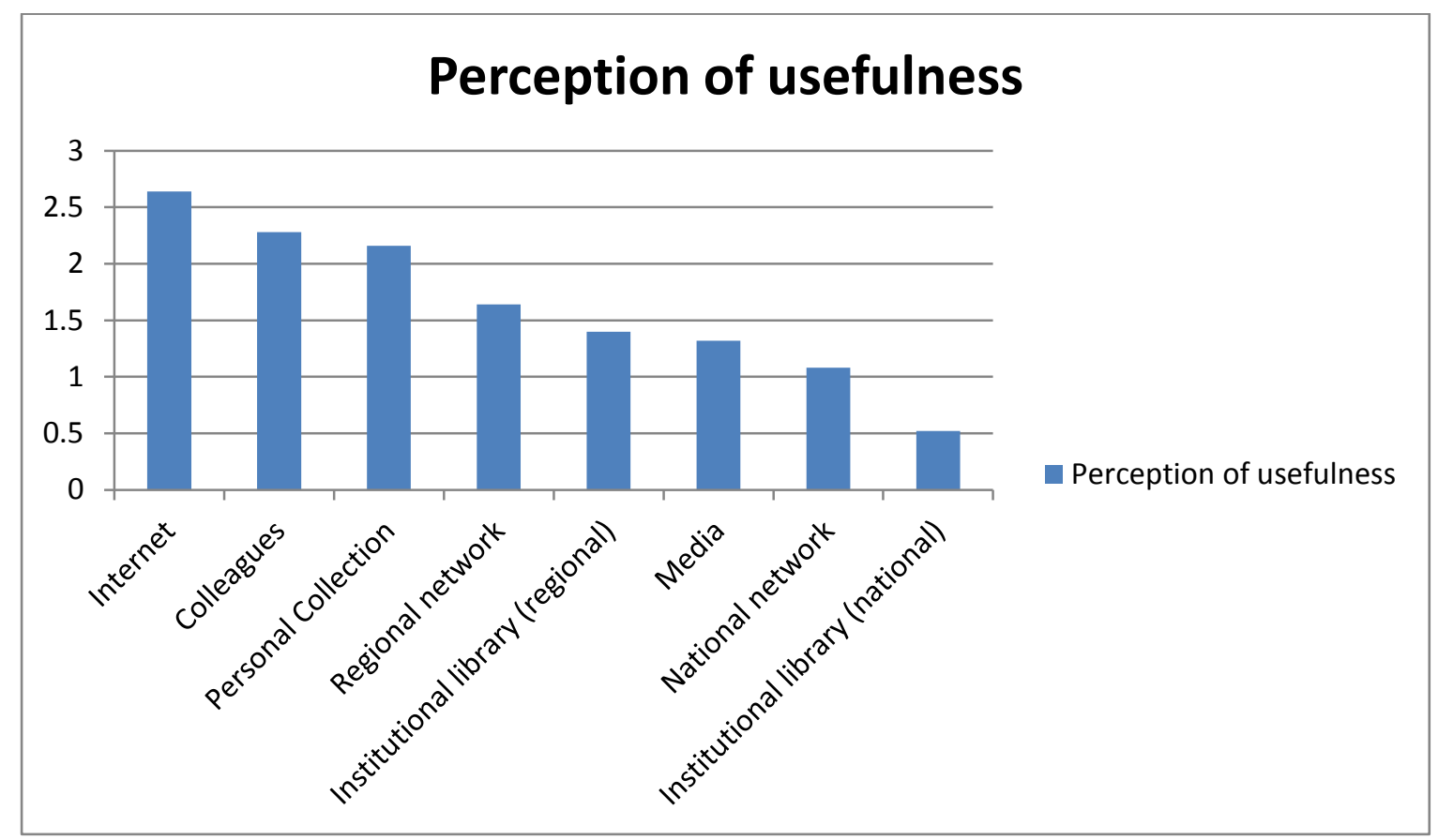

$3=$ very useful

$0=$ neutral 
Information sharing

What are the main reasons why your information is not shared to national and regional networks and partners?

\begin{tabular}{|c|c|c|}
\hline & Response & $\%$ \\
\hline $\begin{array}{l}\text { My information is only relevant to my } \\
\text { work }\end{array}$ & 3 & $12 \%$ \\
\hline I don't have time & 7 & $28 \%$ \\
\hline $\begin{array}{l}\text { There are Information and } \\
\text { Communication Technology limitations }\end{array}$ & 10 & $40 \%$ \\
\hline The data / information is confidential & 7 & $28 \%$ \\
\hline $\begin{array}{l}\text { My employer discourages me from } \\
\text { sharing }\end{array}$ & 1 & $4 \%$ \\
\hline $\begin{array}{l}\text { None of the above - I share my } \\
\text { information with national and regional } \\
\text { networks }\end{array}$ & 10 & $40 \%$ \\
\hline $\begin{array}{l}\text { Other (briefly describe in the space } \\
\text { provided below) }\end{array}$ & 4 & $16 \%$ \\
\hline
\end{tabular}

$40 \%$ of respondents $(10 / 25)$ indicated that they share information with national and regional networks. For the remaining $60 \%$ a number of reasons impeded their sharing of information. The most common barrier to sharing was ICT limitations (10/25) followed by concerns over 
confidentiality (7/25) and a lack of time (7/25). Other responses (copied below) hint at the flow on effects of information overload identified earlier:

\section{Other (briefly describe in the space provided below)}

Doesn't really fit my role and don't want to swamp others with information they are just as likely to have seen as me.

I do try to share as much as possible but I could easily spend all my time working just on that!

expect that others receive too much information already

I share some of my information with regional network, but could do more and don't have time regional partners?

\begin{tabular}{|l|c|c|c|}
\hline \multirow{2}{*}{ Strongly encourages } & & Response & $\%$ \\
\cline { 2 - 4 } & & & $28 \%$ \\
Neither encourages nor discourages & & 10 & $40 \%$ \\
\cline { 2 - 4 } & & & $32 \%$ \\
Discourages & & 0 & $0 \%$ \\
\hline Strongly discourages & & 0 & $0 \%$ \\
\hline
\end{tabular}

$68 \%$ of all employers either encouraged or strongly encouraged respondents to share information. None actively discouraged their employees from doing so. 
Rate the usefulness of the following mechanisms for information sharing

\begin{tabular}{|c|c|c|c|c|c|c|c|c|}
\hline & $\begin{array}{l}\text { Very } \\
\text { useful }\end{array}$ & Useful & $\begin{array}{l}\text { Somewh } \\
\text { at Useful }\end{array}$ & Neutral & $\begin{array}{c}\text { Somewhat } \\
\text { Useless }\end{array}$ & Useless & $\begin{array}{l}\text { Very } \\
\text { Useless }\end{array}$ & $\begin{array}{c}\text { Response } \\
\mathrm{s}\end{array}$ \\
\hline $\begin{array}{l}\text { Emails and } \\
\text { listservs }\end{array}$ & 21 & 4 & 0 & 0 & 0 & 0 & 0 & 25 \\
\hline $\begin{array}{l}\text { Conferences, } \\
\text { meetings and } \\
\text { workshops }\end{array}$ & 7 & 12 & 6 & 0 & 0 & 0 & 0 & 25 \\
\hline $\begin{array}{l}\text { Social media } \\
\text { e.g. Facebook } \\
\text { and Twitter }\end{array}$ & 5 & 6 & 7 & 5 & 1 & 0 & 1 & 25 \\
\hline $\begin{array}{l}\text { Local library } \\
\text { e.g. govt. } \\
\text { dept. }\end{array}$ & 2 & 6 & 6 & 3 & 3 & 2 & 2 & 24 \\
\hline $\begin{array}{l}\text { Regional } \\
\text { library e.g. } \\
\text { SPREP, SPC, } \\
\text { USP etc.) }\end{array}$ & 6 & 7 & 2 & 5 & 4 & 0 & 1 & 25 \\
\hline $\begin{array}{l}\text { Face-to-face } \\
\text { informal } \\
\text { conversations }\end{array}$ & 11 & 10 & 3 & 1 & 0 & 0 & 0 & 25 \\
\hline
\end{tabular}

Emails and listservs were identified as the most useful mechanisms for information sharing with $84 \%(21 / 25)$ rating them as very useful. The next most useful were Face-to-face informal 
conversations with $44 \%(11 / 25)$ rating them as very useful and a further $40 \%(10 / 25)$ useful. All respondents identified Conferences, meetings and workshops as at least somewhat useful. Regional libraries and local libraries were rated as at least being somewhat useful as an information sharing mechanism by $60 \%(15 / 25)$ and $56 \%(15 / 25)$ of respondents respectively. However $20 \%(5 / 25)$ of respondents thought that regional libraries were at least somewhat useless as an information sharing mechanism. This figure rose to $29 \%$ for local institutional libraries (7/24). In contrast, Social Media such as Facebook was thought to be at least somewhat useful by $78 \%$ of respondents $(18 / 25)$ and only $8 \%(2 / 25)$ thought Social media to be at least somewhat useless. When cross tabulating by gender, $85 \%$ (12/14) of female respondents thought Social Media to be at least somewhat useful compared to only $54 \%(6 / 11)$ of male respondents.

$38 \%$ of Pacific respondents rated Social Media as being very useful with a further $61 \%$ believing it to be useful or somewhat useful. In contrast no expats rated Social media as being very useful and only $36 \%$ rated it as useful or somewhat useful. $54 \%(7 / 13)$ of Pacific respondents believed that local institutional libraries were a useful or very useful information sharing mechanism. This figure rises to $77 \%(10 / 13)$ for regional libraries. In contrast the corresponding figures for expats are $10 \%(1 / 10)$ and $37 \%(4 / 11)$. Similarly, $83 \%(5 / 6)$ of national respondents rate regional libraries as useful or very useful mechanisms for information sharing compared to only $54 \%(7 / 13)$ of regional respondents. 


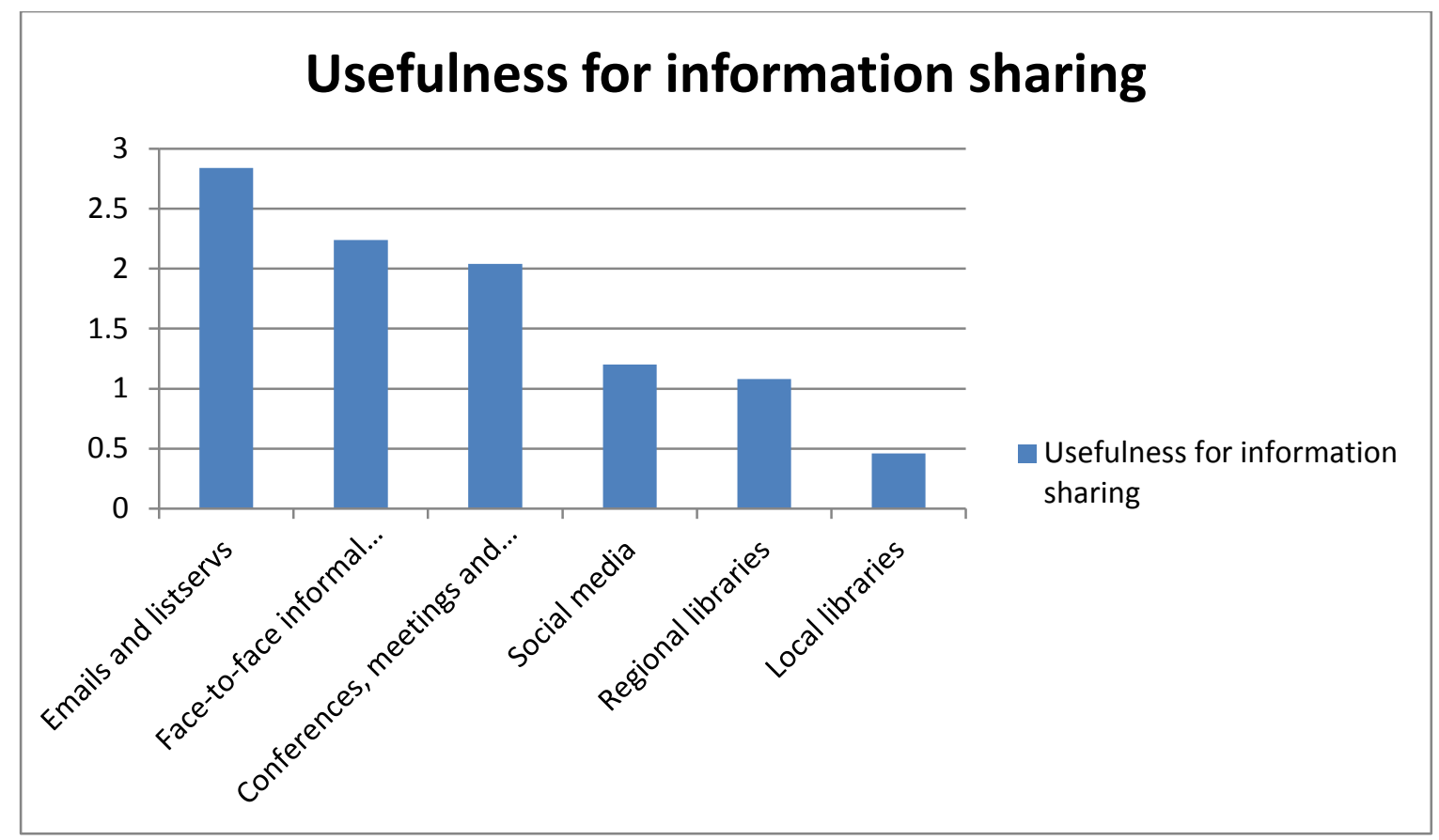

$3=$ very useful

$0=$ neutral 
With whom do you actively share climate change information (more than once a month)

\begin{tabular}{|c|c|c|c|c|c|c|}
\hline & Colleagues & $\begin{array}{l}\text { National } \\
\text { networks }\end{array}$ & $\begin{array}{l}\text { Regional } \\
\text { networks }\end{array}$ & $\begin{array}{l}\text { Local } \\
\text { library } \\
\text { e.g.. govt. } \\
\text { dept. }\end{array}$ & $\begin{array}{l}\text { Regional } \\
\text { library e.g. } \\
\text { SPREP, SPC, } \\
\text { USP etc. }\end{array}$ & Responses \\
\hline $\begin{array}{l}\text { News and } \\
\text { current } \\
\text { awareness }\end{array}$ & 23 & 8 & 11 & 1 & 4 & 47 \\
\hline $\begin{array}{l}\text { Conference, } \\
\text { meeting, } \\
\text { Workshop deta }\end{array}$ & 21 & 9 & 12 & 2 & 3 & 47 \\
\hline $\begin{array}{l}\text { Funding } \\
\text { information }\end{array}$ & 17 & 8 & 12 & 1 & 3 & 41 \\
\hline $\begin{array}{l}\text { Published } \\
\text { reports and } \\
\text { public } \\
\text { documents }\end{array}$ & 23 & 12 & 17 & 6 & 7 & 65 \\
\hline $\begin{array}{l}\text { Unpublished } \\
\text { documents }\end{array}$ & 20 & 7 & 7 & 2 & 2 & 38 \\
\hline Data & 19 & 9 & 10 & 4 & 5 & 47 \\
\hline
\end{tabular}

The most popular targets for information sharing, across all types of information, are colleagues followed by regional and then national networks. Whilst $80 \%(20 / 25)$ of respondents actively share unpublished documents to colleagues and $28 \%(7 / 25)$ to national and regional networks, only $8 \%$ $(2 / 25)$ actively share unpublished documents with either a local or regional library. The figures are 
similar with published reports and public documents twice as likely to be shared with national and regional networks as they are with either a local or regional library. None of the respondents who identified themselves as being from regional organisations actively share unpublished documents with their institutional libraries.

How actively is your institutional library participating in your climate change community as a repository of relevant documents, tools and knowledge?

\begin{tabular}{|l|c|c|c|}
\hline \multirow{2}{*}{ Very active } & & Response & $\%$ \\
\cline { 2 - 4 } & & 8 & $32 \%$ \\
Notive & & 8 & $32 \%$ \\
\hline Not active at all & & 1 & $4 \%$ \\
\hline My institution does not have a library & & 2 & $8 \%$ \\
\hline Total & & 6 & $24 \%$ \\
\hline
\end{tabular}

$64 \%$ of respondents thought that their institutional library was either actively or very actively participating in the climate change community as a repository of relevant documents, tools and knowledge. 


\section{Discussion}

\section{Information needs}

In the face of the torrent of climate change information being published both internationally and regionally in a range of media and by a divergent array of stakeholders the research findings suggest that the primary issue facing this community of practice is not a lack of information or poor access to potential sources of information but too much information without either the time or alternatively the skills to manage and filter the information.

It is critical to note that in the space of a decade there has been a dramatic shift away from almost total reliance on having physical access to hardcopy information to the expectation, as reflected in the survey results, that information needs to be available immediately and able to be accessed and downloaded from the desktop. It is highly questionable, at least at the national level, to what extent libraries in the region have ever adequately supported the hardcopy information needs of stakeholders. What is clear from the results of this survey is that stakeholders are now wanting digital access to current information available from their desktops on demand. A library service model based predominantly on providing bibliographic access to hardcopy documents that are physically located and only able to be accessed from a traditional physical library space does not meet the information needs of the climate change community of practice in the Pacific. There are significant implications for libraries to re-orient their service model to delivery of full text access to information online on demand to client's desktops. Reliance on hardcopy collections located and accessible only from a designated physical library at particular times does not meet user requirements. 


\section{Information seeking}

Within the climate change community of practice, the majority of respondents indicated that they actively seek a wide array of information at least on a weekly basis (in many cases daily) in a range of formats and from a range of sources. In addition to a high demand for climate change news and soft information such as information about funding, meetings and workshops, there is a high demand for access to reports - both published and unpublished - and scientific data. Comparatively, books about climate change were sought less than other types of information but even here, $40 \%$ of respondents indicated seeking books at least on a weekly basis. Journal articles were even more regularly sought by the majority of respondents with $60 \%$ of respondents seeking journal articles at least weekly.

With such a high level of information seeking activity within the community it is striking to note, relative to other information sources how poorly libraries, both at national level and regional level, are rated by respondents in relation to their usefulness and relevance to their work. Whilst, in the Google age, it was perhaps to be expected that the internet as an information source would receive the highest rating (as it did), it was interesting to note that both personal collections and colleagues also rated markedly better than institutional libraries. The high value placed upon personal collections as an information source by many respondents echoes the findings of Leckie et al (1996) that professionals would often seek information from their own collections before going elsewhere. National and regional networks are also more highly valued as information sources than libraries.

The picture that emerges is of a highly active and highly connected community of information seekers, utilising the internet and their collegial, national and regional contacts to build significant personal information collections. Such an information community is organic, responsive, largely informal, and increasingly self-reliant. 
The survey results echoed the findings of Heminger et al (2007) that there has been a dramatic shift away from hardcopy towards electronic access to information. "The transition to primarily electronic communication has the potential to significantly change the ways scholarly communication takes place. These changes range from the convenience of accessing electronic material on the reader's desktop, through the speed at which scholars can communicate new information, to accessibility to larger amounts of the material, and finally to the corresponding problem of sifting through larger amounts of potentially useful materials." (Heminger, 2007).

Within this context there is a very real challenge for libraries at both national and regional level to identify how they can become more useful and relevant to their identified communities of practice and to provide access to resources and services that both meet real information needs and add value to their host institutions.

Zipf's (1949) Principal of Least Effort becomes increasingly significant when examining information seeking behaviour in the internet age (Case, 2002). Librarians at both national and regional level must embrace new internet technologies to make information seeking easier and faster and available from the clients desktop.

Of particular interest are the marked differences in both attitudes and behaviours between regional and in-country national respondents, and between respondents who identified themselves as being expatriate and Pacific islanders. Pacific island respondents placed much higher value on their colleagues, and networks as information sources and perceived libraries both national and regional to be more useful than did their expatriate counterparts for both information seeking and information sharing. All Pacific island respondents also rated social networks as being at least somewhat useful whereas the comparative figure for expatriates was only $44 \%$. National 
respondents rated both the value and usefulness of the regional networks and also the regional libraries considerably more highly than did their counterparts who were located at one of the regional institutions. The perception as to the value and usefulness of the regional libraries is far more positive amongst national and Pacific island respondents when compared to their regional counterparts. The value and utility of local national in-country libraries was rated comparatively poorly by all groups signalling a considerable divide between libraries at the national and regional level. The survey outcomes tend to reinforce the findings of the many reviews and assessments of library capacity at the local level across all sectors in the past two decades that libraries at national level, where they are operational, are little used and poorly supported by their host institutions.

\section{Information sharing}

Perceived institutional competition for resources and influence at both the regional and national level does not appear to impact upon information sharing behaviour of employees, indicative perhaps of a high degree of alignment between the goals and interests of participating organisations (Gharawi and Davies, 2010). A significant number of respondents (40\%) indicated that they actively share information with the main reasons for not sharing cited as ICT limitations and a lack of time. Confidentiality of some information was also an important consideration.

A range of mechanisms were utilised for sharing information. The high value attributed to the use of email and listservs as well as face-to-face informal conversations underlined the role and value of a community of practice that transcends thematic and geographic barriers and blurs distinctions and divisions based on institutional affiliations or hierarchies. Face-to-face sharing of information through conferences, meetings and workshops was also highly valued by respondents. The survey results strongly affirmed the observation made by Dawes et al (2009) that despite expectations that 
network technologies provide opportunities for remote collaboration, face-to-face contact is often important, even indispensable, for many forms of collaboration and knowledge sharing.

It is interesting to note the emergence of social media such as Facebook and Twitter as a mechanism for information sharing in the Pacific. Social media was rated as being more useful than either regional or national libraries as an information sharing mechanism.

The concept of 'incidental information acquisition' (Wilson, 1977) whereby an individual's regular formal and informal habits and routines incl. personal observations, discussions with friends and colleagues and participation in informal communication networks such as email groups and online social networks may also be increasingly of critical significance in the 'new' information landscape.

In line with the findings in relation to information seeking behaviour, libraries again were rated comparatively poorly as a mechanism for information sharing. Indeed there was considerable negative sentiment towards the usefulness of libraries, nationally and regionally, by $20 \%$ of respondents. Respondents were also far more inclined to share information with colleagues and national and regional networks than they were with either national or regional libraries. Indeed just $8 \%$ of respondents indicated that they actively shared unpublished documents or "grey literature" with their institutional library. This is an alarming figure given the demand for access to grey literature within the community and certainly explains to some extent why libraries are not more highly valued as sources of information. There is a very considerable flow of information being shared between colleagues and to a lesser extent through regional and national networks. Only rarely however is this information reaching the libraries. It is interesting however to note that amongst $64 \%$ of respondents there is the perception that institutional libraries are active participants as repositories of relevant documents, tools and knowledge. This would appear to be somewhat at odds with the reality. The research findings suggest that both as an information source 
and as an information sharing mechanism institutional libraries are somewhat isolated from the communities of practice they are there to serve and are both less utilised and less valued than alternative mechanisms for both seeking and sharing information. 


\section{Conclusion: Implications for libraries and models of capacity}

\section{development in the Pacific}

A rapid increase in digital information that is transforming the way in which we source, select, package and deliver information ( Henczel 2006) has implications for both the behaviours and expectations of the information user. Information which may have previously been only available from the physical confines of the institutional library is now available at the users' desktop. What then the role of the library and the librarian and what are the implications for models of capacity building in the Pacific?

Serrat (2010) argues that the role of the information intermediary is to be immersed within the community of practice and the knowledge flow, to monitor and examine the information recognizing themes, recurrent patterns and identifying common critical elements that are particularly relevant to the information needs of the community, and to organise and arrange these resources into coherent and systematic forms for ease of use.

Henczel (2006) highlights two fundamental changes that are impacting upon the way we offer information services in an organisation: an increase in digital information that is altering the way we source, select, purchase, access, store, package and deliver information; a consequent change in the behaviours and expectation of the information users. A deep understanding then of both the structure and composition of information networks as well as the norms and customs for participating within these networks are critical to understanding the knowledge flow. 
The research findings indicate that the climate change community of practice is not homogenous and that there are clear distinctions in both attitudes and behaviours between expatriate and Pacific islanders and also between national and regional stakeholders. The prominence of informal networks for communication and information exchange and the value still ascribed to face-to-face encounters and the development of personal relationships was a dominant theme as was the reliance on internet technologies to acquire and share information. Within this context Pacific libraries within the government sector and at the regional level must redefine their role and the services that they offer if they are to be valued and seen as more useful and relevant to stakeholders within the community.

Owens promotes the Information Resource Management Maturity Model, where the librarian moves from being gatekeeper to information intermediary, through to facilitator, being "embedded in a business context and making connections between business needs and available resources" and ultimately to become the knowledge enabler and catalyst, whereby end users interact with diverse information within their social network. "A highly connected librarian ensures that comprehensive resources are available, people are linked to other people, and technology is optimised" (Owens, 2008, p.12). O'Connor (2007) stresses that while traditional library skills are important, special librarianship places a stronger emphasis on knowledge of the business of the parent organisation and partnerships with library clients.

There is so much information becoming available within the climate change sector that it is increasingly critical to have the knowledge and skills to be able to identify information that is most relevant and valuable. This requires judgment, experience and a deep understanding of the thematic area. The implications for both recruitment, and capacity building for librarians in the government sector at the national level and at the regional agency level is that attention must be 
turned towards skills in communications and facilitation, development of competence with internet based technologies and the aptitude and commitment to develop a deep understanding of the thematic area. In order to be relevant and useful, the librarian must be immersed in the community of practice and participate fully in the communication flow, developing relationships and partnerships with stakeholders through emails and listservs, social networks and face-to-face encounters in both informal and formal settings (meetings, workshops etc.). The librarian must be able to establish linkages between informally operating communities of practice and formalised organisational processes.

In March 2011, the regional Climate Change Roundtable met in Niue. One of the items for consideration was a proposal to build a regional climate change portal. SPREP had commissioned Geoscience Australia to prepare a document outlining the business case for the portal (Jones and Ross, 2011). The objective of the proposed portal development was that the "portal will act as a focus for climate and climate change information relevant to the Pacific, provide up to date information for decision makers, and researchers, and improve communication and collaboration in adaptation initiatives by national, regional and international stakeholders." All of the stakeholders consulted by Geoscience Australia stated that a Pacific Climate Change Portal would be valuable. The main drivers for the success of the portal were identified as:

(a) Relevance of the content, currency and functionality;

(b) Partnerships to ensure on-going relevance and currency;

(c) Adequate on-going resources to provide, update and deliver content, operate the portal, improve functionality and maintain partnerships; and (d) access to portal data and functionality.

The consultancy document noted both the clear need to improve access to information and 
data both nationally and regionally in the Pacific and the absence currently of a region-wide agreed mechanism for collating and disseminating climate-related information. The need for improved communication and collaboration and the value of maximising synergies and reducing duplication between stakeholders was highlighted. Critical to the value and success of any proposed information sharing mechanism was the need for consistent, valid and relevant content and the maintenance of a sustainable information flow between stakeholders. It is significant that nowhere in the consultancy document, nor in the ensuing discussion by stakeholders at the Pacific Climate Change Roundtable, are traditional hardcopy libraries, either at national or regional level, considered. The focus is on enhancing communications flows between stakeholders and utilising internet technology to deliver real-time access to relevant information to the clients desktop. The consultants noted that there were implications for in-country capacity development in Knowledge and Information Management across all types of information and not just climate change information. The release of the climate change portal report (Jones and Ross, 2011) and its consideration at the Pacific Climate Change Roundtable is timely, as it is reflective of the fundamental shift away from traditional models of information management, towards a holistic, internet based model built upon a deep understanding of information flows and communication channels between stakeholders. This shift is strongly represented in the findings of this research project. It is significant that the consultants also stressed that a proposed model for information sharing could not be solely reliant on technology to automate this process, but alternatively that the value and effectiveness of any information sharing mechanism was critically reliant on interpretation, assessment and judgment in selecting, managing and disseminating relevant and valuable information to stakeholders and moreover, that the staff with the skillset most suited for the development and management, at both the regional and national level, of such a mechanism was that of the Information Manager / Librarian. 
Rather than signalling the demise or diminution of the role of the librarian and the library service in the Pacific, the transformation in information seeking and information sharing behaviour and the rapid transition from reliance on hardcopy information to digital, offers the library profession an unprecedented opportunity to reposition itself as a central contributor to effective government and improved decision making and to raise the status and profile of the profession in the region. In order to make the most of this opportunity, there is an urgent need for a reconsideration of the role of traditional library services and models for capacity building and development in knowledge and information management at both regional and national level.

Words: 9,451

\section{References}

De Alwis, G., Majid, S. Chaudyr, A. S. (2006). Transformation in managers' information seeking behaviour: a review of the literature. Journal of Information Science 32(4) pp.363-377.

Borgatti, S. P. \& Cross, R. (2003). A relational view of information seeking and learning in social networks. Management Science Vol.49 No.4 pp.432-445.

Bryman, A (2008). Social research methods. $3^{\text {rd }}$ ed. Oxford, New York: OUP.

Case, D. (2002). Looking for information: A survey of research on information seeking, needs, and behavior. Amsterdam: Academic Press.

Cohen, P. \& Valmei, D. (2008). The Reefbase Pacific project and information portal: delivering information of reef and associated livelihoods, fisheries and biodiversity. Paper presented at the IAMSLIC: Sustainability in a Changing Climate: proceedings of the 34th Annual Conference of the 
International Association of Aquatic and Marine Science Libraries and Information Centers (IAMSLIC). Available from https://darchive.mblwhoilibrary.org/handle/1912/2867

Davies, S. (2007). Report on Pacific Islands region : current issues and suggested future directions. Paper presented at the Nineteenth Session of the IOC Committee on International Oceanographic Data and Information Exchange (IODE-XIX) Trieste, Italy, 12-16 March 2007. Retrieved from http://www.iode.org/index.php?doclD=416\&option=com oe\&task=viewDocumentRecord

Davy, C. (2006). Recipients: the key to information transfer. Knowledge Management Research \& Practice (2006) 4, pp.7-25.

Dawes, S. S., Cresswell, A. M. \& Pardo, T. A. (2009) From "need to know" to "need to share": tangled problems, information boundaries, and the building of public sector knowledge networks. Public Administration Review Vol.69 Iss.3 pp.392-402.

Fa'asili, U. \&Williams, E. (1987). Pacific Island Marine Resources Information System (PIMRIS. Part II marine resources information needs: country reports. Suva: University of the South Pacific.

Flores, B. (1983). A marine resources information system for the Pacific? Fiji Library Association Journal, (10) Dec 83, 55-63.

Ford, D. P. \& Staples, D. S. (2006). Perceived value of knowledge: the potential informer's perception. Knowledge Management Research \& Practice (2006) 4: pp.3-16.

Foster, A. (2004). A nonlinear model of information-seeking behaviour. Journal of the American Society for Information Science and Technology 55(3) pp.228-237.

Gharawi, M. A., Dawes, S. S. (2010). Conceptualising knowledge and information sharing in transnational government networks CTG Working Papers No.01-2010 pp1-16.

Heminger , B. M., Lu, D., Vaughan, K T L , Adams, S. J. (2007). Information seeking behavior of academic scientists. Journal of the American Society for Information Science and Technology, 58 
(14): pp.2205-2225.

Henczel, S. (2006). Measuring and evaluating the library's contribution to organizational success. Performance Measurement and Metrics, Vol. 7 No.1 2006 pp.7-16.

Howard, L. S. (1983). Introduction: scientific and technological information. Fiji Library Association Journal, (10) Dec. 83, 1-4.

Jones, T. D. and Ross, R. (2011). Towards a Business Case for a Pacific Climate Change Portal - Final Report. Geoscience Australia Professional Opinion No. 2011/03.

Lal, M. (1993). Development of standards for special libraries in Fiji. Fiji Library Association Journal (29) Dec 93, p.33-36.

Leckie, G. J., Pettigrew, K. E. \& Sylvain, C. (1996). Modeling the information seeking of professionals: a general model derived from research on engineers, health care professionals, and lawyers. The Library Quarterly Vol.66 No.2 pp.161-193.

McDowell, R. \& Creech, H. (1991) Information control and the aquatic environment of the south pacific. (SOPAC Miscellaneous Report 119). Suva, Fiji: SOPAC

Mamtora, J. (2001). Bridging the digital divide in the islands of Oceania. Paper presented at the $67^{\text {th }}$ IFLA Council and General Conference August 16-25, 2001. Retrieved from http://archive.ifla.org/IV/ifla67/papers/169-163e.pdf

Nelson, C. (2006). PIMRIS status report December 2006. Suva, Fiji: University of the South Pacific. Neumann, William Lawrence.(2003). Social research methods: qualitative and quantitative approaches. $5^{\text {th }}$ ed. Boston: Allyn and Bacon.

Nicholas, D. Huntington, P. Williams, P. \& Dobrowolski, T. (2004). Re-appraising information seeking behaviour in a digital environment. Journal of Documentation Vol.60 No.1 pp.24-43.

O'Connor, A. (2007). Special Libraries and information services. In Ferguson, S. (Ed.) 
Libraries in the twenty-first century: Charting new directions in information services ( $p p$.

59-72). Wagga Wagga, NSW: Centre for Information Studies, Charles Sturt University

Owens, L. (2008). Best practices: Reinventing the corporate library. Retrieved from

http://www.forrester.com/rb/Research/best_practices_reinventing_corporate_library_/ $\mathrm{q} / \mathrm{id} / 45356 / \mathrm{t} / 2$

Park, J., Konana, P., Gu, B., \& Man Leung, A. C. (2010). A investigation of information sharing and seeking behaviour in virtual communities. ICIS 2010 Proceedings. Paper 242.

Prasad, H. (1983). Agricultural information services in Fiji. Fiji Library Association Journal, (10) Dec. $83,23-30$.

Serrat, O. (2008). Notions of knowledge management. Knowledge Solutions. Retrieved from http://www.adb.org/Documents/Information/Knowledge-Solutions/Notions-KnowledgeManagement.pdf

Serrat, O. (2008). Building communities of practice. Knowledge Solutions. Retrieved from http://www.adb.org/Documents/Information/Knowledge-Solutions/Building-Communities$\underline{\text { Practice.pdf }}$

Serrat, O. (2009). Building networks of practice. Knowledge Solutions. Retrieved from http://www.adb.org/Documents/Information/Knowledge-Solutions/Building-Networks-of-

\section{Practice.pdf}

Serrat, O. (2009). Social network analysis. Knowledge Solutions. Retrieved from http://www.adb.org/Documents/Information/Knowledge-Solutions/Social-Network-Analysis.pdf Serrat, O. (2010). Bridging organisational silos. Knowledge Solutions. Retrieved from http://www.adb.org/documents/information/knowledge-solutions/bridging-organizational-silos.pdf Serrat, O. (2010). Harvesting knowledge. Knowledge Solutions. Retrieved from http://www.adb.org/documents/information/knowledge-solutions/harvesting-knowledge.pdf 
Tanner, K. (2002). Survey research. In Williamson, K. Research methods for students, academics and professional: Information management and systems ( $2^{\text {nd }}$ ed., pp.89-109). Wagga Wagga, NSW: Centre for Information Studies, Charles Sturt University.

Thomas-Hunt, M. C., Ogden, T. Y. \& Neale, M. A. Who's really sharing? Effects of social and expert status on knowledge exchange within groups. Management Science Vol.49, No.4 pp.464-477.

UK Department for International Development. (n.d.). Capacity Development: Where Do We Stand Now? Available from

http://info.worldbank.org/etools/library/view p.asp?lprogram=102\&objectid=114227

Walton, P. (1990). Agricultural information collection, storage and dissemination in the Pacific island region. Fiji Library Association Journal (24) 1990 pp.21-35.

Walton, P. (2006). Assessment of agricultural information needs in African, Caribbean and Pacific (ACP) states for CTA's products and services: Pacific: overview regional report final report .

Retrieved from http://www.ink4dev.net/filesstk/Overview report Pacific f2.doc

Walton, P. \& Erasito, E. (2003). Report of the evaluation of SPREP Information Resource Centre and Pacific Environmental Information Network. Suva, Fiji: Eco-Consult Pacific Co. Ltd.

Williams, E. (1983). Access to scientific and technological information: Fiji and the South Pacific. Fiji Library Association Journal, (10) Dec 83, 5-21.

Williamson, K. (1998). Discovered by chance: the role of incidental information acquisition in an ecological model of information use. Library \& Information Science Research Vol.20 No.1 pp.23-40

Wilson, Patrick. (1977). Public knowledge, private ignorance. Westport, CT: Greenwood Press.

Zipf, George Kingsley. (1949). Human behaviour and the principle of least effort.

Oxford, England: Addison-Wesley Press. 


\section{Appendices}

\section{Information Sheet}

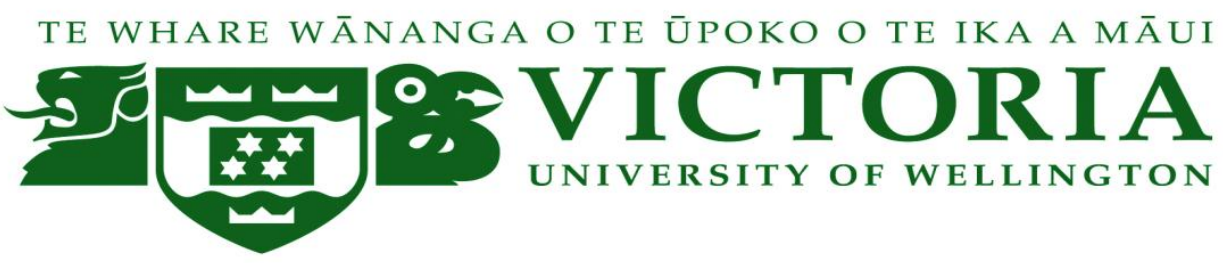

Participant Information Sheet for a Study of 'Information Seeking and Information Sharing

Behaviour in the climate change community of practice in the Pacific'

Researcher: Peter Murgatroyd: School of Information Management, Victoria University of Wellington

I am a Masters student in Information Management at Victoria University of Wellington. As part of this degree I am undertaking a research project leading to a thesis. The project I am undertaking is: “Focusing on one 'community of practice' - climate change - to examine the extent to which current models of library service in scientific and technical libraries in the Pacific region are aligned to the information needs (information seeking and information sharing) of stakeholders". The University requires that ethics approval be obtained for research involving human participants. 
I am inviting employees of Pacific regional organisations, Pacific government departments, ministries and NGOs who work in the climate change community of practice in the Pacific to participate in this study. Participants will be asked to complete a short questionnaire. It is envisaged that the questionnaire will take about 10 minutes to complete and may be completed in your own time .

Please complete the survey by clicking on the following link http://vuw.qualtrics.com/SE/?SID=SV 8JmTTTqNKeggAao

Please note that the survey is strictly anonymous. Responses collected will form the basis of my research project and will be put into a written report. It will not be possible for you to be identified personally. Only grouped responses will be presented in this report. All material collected will be kept confidential. No other person besides me and my supervisor, Dr Philip Calvert, will see the questionnaires. The thesis will be submitted for marking to the School of Information Management and deposited in the University Library. It is intended that one or more articles will be submitted for publication in scholarly journals. A summary of research results will be made available and circulated to all participants. Questionnaires will be destroyed two years after the end of the project.

If you have any questions or would like to receive further information about the project, please contact me at murgatpete@myvuw.ac.nz or my supervisor, Dr Philip Calvert, at the School of Information Management at Victoria University,

P O Box 600, Wellington, phone 644 463-5103

Peter Murgatroyd 


\section{What is the greatest information challenge that you face?}

\section{[choose one response]}

\begin{tabular}{|c|l|c|c|c|}
\hline$\#$ & Answer & Response & $\%$ \\
\hline 1 & Managing information overload & 9 & $36 \%$ \\
\hline 2 & $\begin{array}{l}\text { Finding relevant filtered information that } \\
\text { meets your needs }\end{array}$ & & 9 & $36 \%$ \\
\hline 3 & $\begin{array}{l}\text { Filling gaps in your knowledge base } \\
4\end{array}$ & Keeping current and up-to-date & 4 & $16 \%$ \\
\hline 5 & $\begin{array}{l}\text { Other (briefly describe in the space } \\
\text { provided below) }\end{array}$ & & 2 & $8 \%$ \\
\hline & Total & 1 & $4 \%$ \\
\hline
\end{tabular}

Other (briefly describe in the space provided below)

Finding the right information again among information previously collected

\begin{tabular}{|l|r|}
\hline Statistic & Value \\
\hline Min Value & 1 \\
Max Value & 5 \\
Mean & 2.08 \\
Variance & 1.24 \\
Standard Deviation & 1.12 \\
Total Responses & 25 \\
\hline
\end{tabular}




\section{What are the most important features when seeking}

\section{information?}

\begin{tabular}{|c|c|c|c|c|c|c|}
\hline \# & Question & Essential & Desirable & $\begin{array}{l}\text { Not an important } \\
\text { consideration }\end{array}$ & Responses & Mean \\
\hline 1 & Information is available immediately & 15 & 10 & 0 & 25 & 1.40 \\
\hline 2 & $\begin{array}{l}\text { Information is available at low cost } \\
\text { (or free) }\end{array}$ & 15 & 8 & 2 & 25 & 1.48 \\
\hline 3 & Information is up-to-date & 18 & 7 & 0 & 25 & 1.28 \\
\hline 4 & $\begin{array}{l}\text { I am able to access and download the } \\
\text { information from my desktop }\end{array}$ & 17 & 8 & 0 & 25 & 1.32 \\
\hline 5 & $\begin{array}{l}\text { The information is authored or } \\
\text { endorsed by a recognised expert or } \\
\text { authority }\end{array}$ & 15 & 7 & 3 & 25 & 1.52 \\
\hline 6 & $\begin{array}{l}\text { The information is packaged and } \\
\text { filtered to meet my information need }\end{array}$ & 11 & 7 & 6 & 24 & 1.79 \\
\hline
\end{tabular}

\begin{tabular}{|c|c|c|c|c|c|c|}
\hline Statistic & $\begin{array}{l}\text { Information } \\
\text { is available } \\
\text { immediately }\end{array}$ & $\begin{array}{l}\text { Information } \\
\text { is available } \\
\text { at low cost } \\
\text { (or free) }\end{array}$ & $\begin{array}{l}\text { Information } \\
\text { is up-to- } \\
\text { date }\end{array}$ & $\begin{array}{l}\text { I am able to } \\
\text { access and } \\
\text { download the } \\
\text { information } \\
\text { from my } \\
\text { desktop }\end{array}$ & $\begin{array}{l}\text { The } \\
\text { information is } \\
\text { authored or } \\
\text { endorsed by a } \\
\text { recognised } \\
\text { expert or } \\
\text { authority }\end{array}$ & $\begin{array}{c}\text { The } \\
\text { information is } \\
\text { packaged and } \\
\text { filtered to } \\
\text { meet my } \\
\text { information } \\
\text { need }\end{array}$ \\
\hline Min Value & 1 & 1 & 1 & 1 & 1 & 1 \\
\hline Max Value & 2 & 3 & 2 & 2 & 3 & 3 \\
\hline Mean & 1.40 & 1.48 & 1.28 & 1.32 & 1.52 & 1.79 \\
\hline Variance & 0.25 & 0.43 & 0.21 & 0.23 & 0.51 & 0.69 \\
\hline $\begin{array}{l}\text { Standard } \\
\text { Deviation }\end{array}$ & 0.50 & 0.65 & 0.46 & 0.48 & 0.71 & 0.83 \\
\hline $\begin{array}{l}\text { Total } \\
\text { Responses }\end{array}$ & 25 & 25 & 25 & 25 & 25 & 24 \\
\hline
\end{tabular}




\section{What are the main reasons why your information is not shared}

\section{to national and regional networks and partners? [choose as many}

\section{responses as appropriate]}

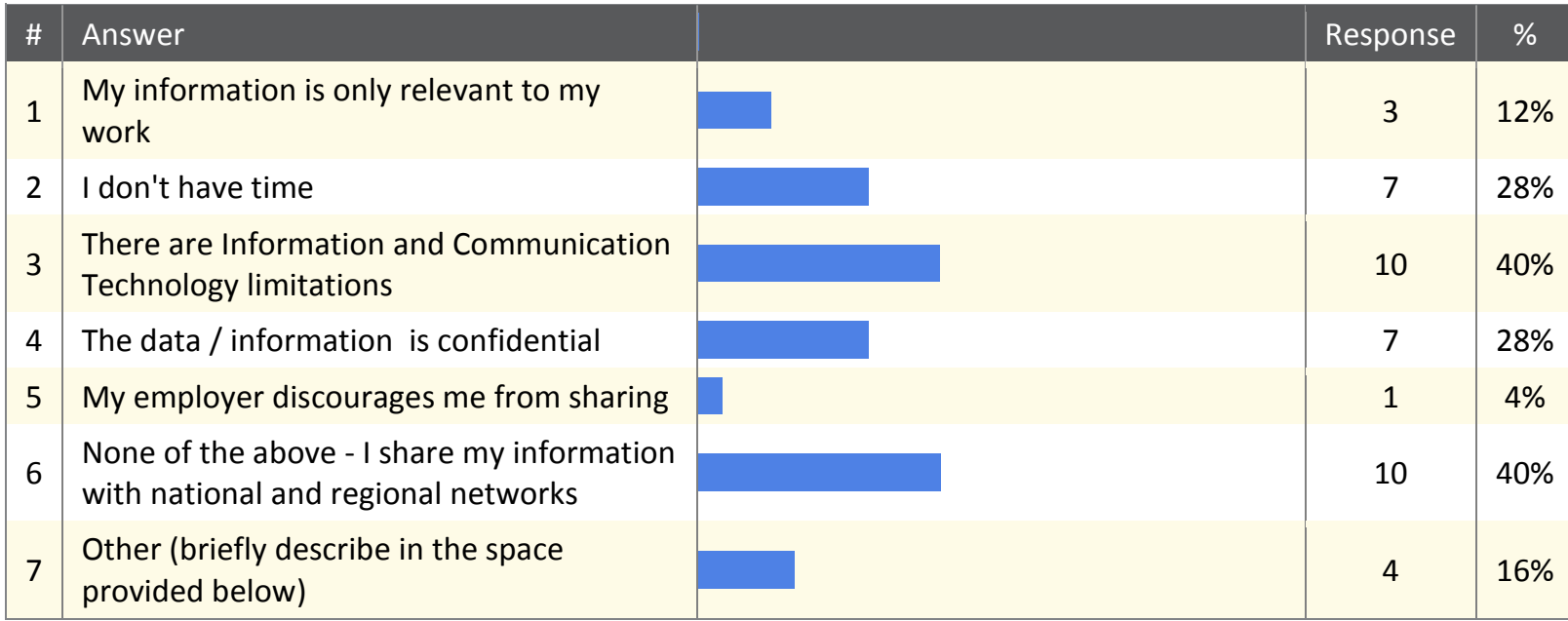

\section{Other (briefly describe in the space provided below)}

Doesn't really fit my role and don't want to swamp others with information they are just as likely to have seen as me.

I do try to share as much as possible but I could easily spend all my time working just on that! expect that others receive too much information already

I share some of my information with regional network, but could do more and don't have time

\begin{tabular}{|l|r|}
\hline Statistic & Value \\
\hline Min Value & 1 \\
Max Value & 7 \\
Total Responses & 25 \\
\hline
\end{tabular}




\section{Does your employer encourage and/or actively enable sharing of information to national and regional partners? [choose one response]}

\begin{tabular}{|c|l|c|c|c|}
\hline$\#$ & Answer & Response & $\%$ \\
\hline 1 & Strongly encourages & 7 & $28 \%$ \\
2 & Encourages & 10 & $40 \%$ \\
3 & Neither encourages nor discourages & 8 & $32 \%$ \\
4 & Discourages & 0 & $0 \%$ \\
\hline 5 & Strongly discourages & 0 & $0 \%$ \\
\hline & Total & 25 & $100 \%$ \\
\hline
\end{tabular}

\begin{tabular}{|l|r|}
\hline Statistic & Value \\
\hline Min Value & 1 \\
Max Value & 3 \\
Mean & 2.04 \\
Variance & 0.62 \\
Standard Deviation & 0.79 \\
Total Responses & 25 \\
\hline
\end{tabular}

\section{How actively is your institutional library participating in your}

climate change community as a repository of relevant documents, tools and knowledge? [choose one response]

\begin{tabular}{|c|l|c|c|c|}
\hline$\#$ & Answer & Response & $\%$ \\
\hline 1 & Very active & 8 & $32 \%$ \\
2 & Active & 8 & $32 \%$ \\
3 & Not very active & 1 & $4 \%$ \\
4 & Not active at all & 2 & $8 \%$ \\
5 & My institution does not have a library & 6 & $24 \%$ \\
\hline & Total & 25 & $100 \%$ \\
\hline
\end{tabular}




\begin{tabular}{|l|r|}
\hline Statistic & Value \\
\hline Min Value & 1 \\
Max Value & 5 \\
Mean & 2.60 \\
Variance & 2.58 \\
Standard Deviation & 1.61 \\
Total Responses & 25 \\
\hline
\end{tabular}

6. Rate the following information sources of climate change information in relation to their usefulness and relevance to your work

\begin{tabular}{|c|c|c|c|c|c|c|c|c|c|c|}
\hline$\#$ & Question & $\begin{array}{l}\text { Very } \\
\text { usefu } \\
\text { I }\end{array}$ & $\begin{array}{c}\text { Usefu } \\
\text { I }\end{array}$ & $\begin{array}{c}\text { Somewha } \\
\text { t Useful }\end{array}$ & $\begin{array}{c}\text { Neutra } \\
\text { I }\end{array}$ & $\begin{array}{c}\text { Somewha } \\
\text { t Useless }\end{array}$ & $\begin{array}{c}\text { Useles } \\
\mathrm{s}\end{array}$ & $\begin{array}{l}\text { Very } \\
\text { Useles } \\
\text { s }\end{array}$ & $\begin{array}{c}\text { Response } \\
\mathrm{s}\end{array}$ & $\begin{array}{c}\text { Mea } \\
n\end{array}$ \\
\hline 1 & $\begin{array}{l}\text { Internet } \\
\text { (via Google } \\
\text { search) }\end{array}$ & 17 & 7 & 1 & 0 & 0 & 0 & 0 & 25 & 1.36 \\
\hline 2 & $\begin{array}{l}\text { Personal } \\
\text { collection }\end{array}$ & 11 & 10 & 2 & 1 & 1 & 0 & 0 & 25 & 1.84 \\
\hline 3 & Colleagues & 13 & 6 & 6 & 0 & 0 & 0 & 0 & 25 & 1.72 \\
\hline 4 & $\begin{array}{l}\text { National } \\
\text { network }\end{array}$ & 7 & 4 & 5 & 2 & 4 & 2 & 0 & 24 & 2.92 \\
\hline 5 & $\begin{array}{l}\text { Regional } \\
\text { network }\end{array}$ & 11 & 2 & 7 & 2 & 3 & 0 & 0 & 25 & 2.36 \\
\hline 6 & $\begin{array}{l}\text { Institutiona } \\
\text { I library - } \\
\text { local (e.g. } \\
\text { govt. dept.) }\end{array}$ & 3 & 5 & 4 & 8 & 1 & 3 & 1 & 25 & 3.48 \\
\hline 7 & $\begin{array}{l}\text { Institutiona } \\
\text { I library - } \\
\text { regional } \\
\text { (e.g. } \\
\text { SPREP, } \\
\text { SPC, USP } \\
\text { etc.) }\end{array}$ & 8 & 5 & 4 & 6 & 1 & 1 & 0 & 25 & 2.60 \\
\hline 8 & The media & 5 & 8 & 6 & 2 & 4 & 0 & 0 & 25 & 2.68 \\
\hline
\end{tabular}




\begin{tabular}{|l|c|c|c|c|c|c|c|c|}
\hline Statistic & $\begin{array}{c}\text { Internet } \\
\text { (via } \\
\text { Google } \\
\text { search) }\end{array}$ & $\begin{array}{c}\text { Personal } \\
\text { collection }\end{array}$ & Colleagues & $\begin{array}{c}\text { National } \\
\text { network }\end{array}$ & $\begin{array}{c}\text { Regional } \\
\text { network }\end{array}$ & $\begin{array}{c}\text { Institutional } \\
\text { library - } \\
\text { local (e.g. } \\
\text { govt. dept.) }\end{array}$ & $\begin{array}{c}\text { Institutional } \\
\text { library - } \\
\text { regional } \\
\text { (e.g. SPREP, } \\
\text { SPC, USP } \\
\text { etc.) }\end{array}$ & $\begin{array}{c}\text { The } \\
\text { media }\end{array}$ \\
\hline Min Value & 1 & 1 & 1 & 1 & 1 & 1 & 1 & 1 \\
Max Value & 3 & 5 & 3 & 6 & 5 & 7 & 6 & 5 \\
Mean & 1.36 & 1.84 & 1.72 & 2.92 & 2.36 & 3.48 & 2.60 & 2.68 \\
Variance & 0.32 & 1.06 & 0.71 & 2.95 & 2.07 & 2.76 & 2.17 & 1.81 \\
Standard & 0.57 & 1.03 & 0.84 & 1.72 & 1.44 & 1.66 & 1.47 & 1.35 \\
Deviation & 25 & 25 & 25 & 24 & 25 & 25 & 25 & 25 \\
\hline $\begin{array}{l}\text { Total } \\
\text { Responses }\end{array}$ & 25 & & & & & & & \\
\hline
\end{tabular}

\section{How often do you look for the following types of information?}

\begin{tabular}{|c|c|c|c|c|c|c|c|c|c|c|}
\hline \# & Question & Daily & $\begin{array}{c}2-3 \\
\text { Times } \\
a \\
\text { Week }\end{array}$ & $\begin{array}{c}\text { Once } \\
\text { a } \\
\text { Week }\end{array}$ & $\begin{array}{c}2-3 \\
\text { Times a } \\
\text { Month }\end{array}$ & $\begin{array}{l}\text { Once a } \\
\text { Month }\end{array}$ & $\begin{array}{l}\text { Less } \\
\text { than } \\
\text { Once a } \\
\text { Month }\end{array}$ & Never & Responses & Mean \\
\hline 1 & Scientific data & 3 & 5 & 7 & 3 & 4 & 1 & 1 & 24 & 3.29 \\
\hline 2 & $\begin{array}{l}\text { Published } \\
\text { reports }\end{array}$ & 3 & 8 & 6 & 2 & 3 & 2 & 1 & 25 & 3.16 \\
\hline 3 & $\begin{array}{l}\text { Unpublished } \\
\text { reports }\end{array}$ & 2 & 7 & 6 & 3 & 3 & 1 & 3 & 25 & 3.52 \\
\hline 4 & $\begin{array}{l}\text { Climate change } \\
\text { news }\end{array}$ & 12 & 6 & 4 & 0 & 1 & 2 & 0 & 25 & 2.12 \\
\hline 5 & $\begin{array}{l}\text { Conference / } \\
\text { Meeting / } \\
\text { Workshop } \\
\text { details }\end{array}$ & 3 & 5 & 5 & 2 & 8 & 1 & 1 & 25 & 3.56 \\
\hline 6 & $\begin{array}{l}\text { Funding } \\
\text { information }\end{array}$ & 4 & 2 & 4 & 3 & 5 & 5 & 2 & 25 & 4.04 \\
\hline 7 & Journal articles & 2 & 6 & 7 & 2 & 1 & 4 & 2 & 24 & 3.58 \\
\hline 8 & $\begin{array}{l}\text { Books about } \\
\text { climate change }\end{array}$ & 1 & 4 & 5 & 4 & 5 & 3 & 3 & 25 & 4.16 \\
\hline
\end{tabular}




\begin{tabular}{|l|c|c|c|c|c|c|c|c|}
\hline Statistic & $\begin{array}{c}\text { Scientific } \\
\text { data }\end{array}$ & $\begin{array}{c}\text { Published } \\
\text { reports }\end{array}$ & $\begin{array}{c}\text { Unpublished } \\
\text { reports }\end{array}$ & $\begin{array}{c}\text { Climate } \\
\text { change } \\
\text { news }\end{array}$ & $\begin{array}{c}\text { Conference } \\
\text { / Meeting / } \\
\text { Workshop } \\
\text { details }\end{array}$ & $\begin{array}{c}\text { Funding } \\
\text { information }\end{array}$ & $\begin{array}{c}\text { Journal } \\
\text { articles }\end{array}$ & $\begin{array}{c}\text { Books } \\
\text { about } \\
\text { climate } \\
\text { change }\end{array}$ \\
\hline Min Value & 1 & 1 & 1 & 1 & 1 & 1 & 1 & 1 \\
Max Value & 7 & 7 & 7 & 6 & 7 & 7 & 7 & 7 \\
Mean & 3.29 & 3.16 & 3.52 & 2.12 & 3.56 & 4.04 & 3.58 & 4.16 \\
Variance & 2.56 & 2.81 & 3.34 & 2.36 & 2.84 & 3.79 & 3.47 & 3.06 \\
Standard & 1.60 & 1.68 & 1.83 & 1.54 & 1.69 & 1.95 & 1.86 & 1.75 \\
Deviation & 24 & 25 & 25 & 25 & 25 & 25 & 24 & 25 \\
\hline $\begin{array}{l}\text { Total } \\
\text { Responses }\end{array}$ & 24 & & & & & & & \\
\hline
\end{tabular}

\section{Rate the usefulness of the following mechanisms for information sharing}

\begin{tabular}{|c|c|c|c|c|c|c|c|c|c|c|}
\hline \# & Question & $\begin{array}{l}\text { Very } \\
\text { usefu } \\
\text { I }\end{array}$ & $\begin{array}{c}\text { Usefu } \\
\quad\end{array}$ & $\begin{array}{c}\text { Somewha } \\
\text { t Useful }\end{array}$ & $\begin{array}{c}\text { Neutra } \\
1\end{array}$ & $\begin{array}{c}\text { Somewha } \\
\text { t Useless }\end{array}$ & $\begin{array}{c}\text { Useles } \\
\mathrm{s}\end{array}$ & $\begin{array}{l}\text { Very } \\
\text { Useles } \\
\text { s }\end{array}$ & $\begin{array}{c}\text { Response } \\
\mathrm{s}\end{array}$ & $\begin{array}{c}\text { Mea } \\
n\end{array}$ \\
\hline 1 & $\begin{array}{l}\text { Emails and } \\
\text { listservs }\end{array}$ & 21 & 4 & 0 & 0 & 0 & 0 & 0 & 25 & 1.16 \\
\hline 2 & $\begin{array}{l}\text { Conferences, } \\
\text { meetings } \\
\text { and } \\
\text { workshops }\end{array}$ & 7 & 12 & 6 & 0 & 0 & 0 & 0 & 25 & 1.96 \\
\hline 3 & $\begin{array}{l}\text { Social media } \\
\text { e.g. } \\
\text { Facebook } \\
\text { and Twitter }\end{array}$ & 5 & 6 & 7 & 5 & 1 & 0 & 1 & 25 & 2.80 \\
\hline 4 & $\begin{array}{l}\text { Local library } \\
\text { e.g. govt. } \\
\text { dept. }\end{array}$ & 2 & 6 & 6 & 3 & 3 & 2 & 2 & 24 & 3.54 \\
\hline 5 & $\begin{array}{l}\text { Regional } \\
\text { library e.g. } \\
\text { SPREP, SPC, } \\
\text { USP etc.) }\end{array}$ & 6 & 7 & 2 & 5 & 4 & 0 & 1 & 25 & 2.92 \\
\hline 6 & $\begin{array}{l}\text { Face-to-face } \\
\text { informal } \\
\text { conversation } \\
\mathrm{s}\end{array}$ & 11 & 10 & 3 & 1 & 0 & 0 & 0 & 25 & 1.76 \\
\hline
\end{tabular}




\begin{tabular}{|l|c|c|c|c|c|c|}
\hline Statistic & $\begin{array}{c}\text { Emails } \\
\text { and } \\
\text { listservs }\end{array}$ & $\begin{array}{c}\text { Conferences, } \\
\text { meetings and } \\
\text { workshops }\end{array}$ & $\begin{array}{c}\text { Social media } \\
\text { e.g. Facebook } \\
\text { and Twitter }\end{array}$ & $\begin{array}{c}\text { Local } \\
\text { library } \\
\text { e.g.govt. } \\
\text { dept. }\end{array}$ & $\begin{array}{c}\text { Regional } \\
\text { library e.g. } \\
\text { SPREP, SPC, } \\
\text { USP etc.) }\end{array}$ & $\begin{array}{c}\text { Face-to-face } \\
\text { informal } \\
\text { conversations }\end{array}$ \\
\hline Min Value & 1 & 1 & 1 & 1 & 1 & 1 \\
Max Value & 2 & 3 & 7 & 7 & 7 & 4 \\
Mean & 1.16 & 1.96 & 2.80 & 3.54 & 2.92 & 1.76 \\
Variance & 0.14 & 0.54 & 2.08 & 3.13 & 2.83 & 0.69 \\
$\begin{array}{l}\text { Standard } \\
\text { Deviation }\end{array}$ & 0.37 & 0.73 & 1.44 & 1.77 & 1.68 & 0.83 \\
$\begin{array}{l}\text { Total } \\
\text { Responses }\end{array}$ & 25 & 25 & 25 & 24 & 25 & 25 \\
\hline
\end{tabular}

\section{With whom do you actively share climate change information}

(more than once a month) [choose as many responses as

\section{appropriate]}

\begin{tabular}{|c|c|c|c|c|c|c|c|}
\hline$\#$ & Question & Colleagues & $\begin{array}{l}\text { National } \\
\text { networks }\end{array}$ & $\begin{array}{l}\text { Regional } \\
\text { networks }\end{array}$ & $\begin{array}{l}\text { Local } \\
\text { library e.g.. } \\
\text { govt. dept. }\end{array}$ & $\begin{array}{l}\text { Regional library } \\
\text { e.g. SPREP, } \\
\text { SPC, USP etc. }\end{array}$ & Responses \\
\hline 1 & $\begin{array}{l}\text { News and current } \\
\text { awareness }\end{array}$ & 23 & 8 & 11 & 1 & 4 & 47 \\
\hline 2 & $\begin{array}{l}\text { Conference, } \\
\text { meeting, } \\
\text { Workshop details }\end{array}$ & 21 & 9 & 12 & 2 & 3 & 47 \\
\hline 3 & $\begin{array}{l}\text { Funding } \\
\text { information }\end{array}$ & 17 & 8 & 12 & 1 & 3 & 41 \\
\hline 4 & $\begin{array}{l}\text { Published reports } \\
\text { and public } \\
\text { documents }\end{array}$ & 23 & 12 & 17 & 6 & 7 & 65 \\
\hline 5 & $\begin{array}{l}\text { Unpublished } \\
\text { documents }\end{array}$ & 20 & 7 & 7 & 2 & 2 & 38 \\
\hline 6 & Data & 19 & 9 & 10 & 4 & 5 & 47 \\
\hline
\end{tabular}




\begin{tabular}{|l|c|c|c|c|c|c|}
\hline Statistic & $\begin{array}{c}\text { News and } \\
\text { current } \\
\text { awareness }\end{array}$ & $\begin{array}{c}\text { Conference, } \\
\text { meeting, } \\
\text { Workshop details }\end{array}$ & $\begin{array}{c}\text { Funding } \\
\text { information }\end{array}$ & $\begin{array}{c}\text { Published } \\
\text { reports and } \\
\text { public } \\
\text { documents }\end{array}$ & $\begin{array}{c}\text { Unpublished } \\
\text { documents }\end{array}$ & Data \\
\hline Min Value & 1 & 1 & 1 & 1 & 1 & 1 \\
Max Value & 5 & 5 & 5 & 5 & 5 & 5 \\
Total & 24 & 23 & 19 & 24 & 22 & 21 \\
Responses & 24 & & & & & \\
\hline
\end{tabular}

\section{Complete the table choosing the options that best describe you}

\section{[choose as many responses as are appropriate]}

\begin{tabular}{|c|l|c|c|c|}
\hline$\#$ & Question & Yes & Responses & Mean \\
\hline 1 & Male & 11 & 11 & 1.00 \\
2 & Female & 14 & 14 & 1.00 \\
3 & Aged 18-30 & 3 & 3 & 1.00 \\
4 & Aged 31-45 & 14 & 14 & 1.00 \\
5 & Aged 46-65 & 8 & 8 & 1.00 \\
8 & I work in a management role & 10 & 10 & 1.00 \\
9 & I work in a policy / planning role & 12 & 12 & 1.00 \\
10 & I am a technical specialist or adviser & 12 & 12 & 1.00 \\
11 & I am a librarian or information officer & 2 & 2 & 1.00 \\
12 & I work in a National institution e.g. govt. dept. & 6 & 6 & 1.00 \\
13 & I work for a regional or international organisation e.g. SPREP, SPC, USP, FAO & 13 & 13 & 1.00 \\
\hline 14 & etc. I am a Pacific Islander & 13 & 13 & 1.00 \\
15 & I am an expatriate & 11 & 11 & 1.00 \\
\hline
\end{tabular}




\begin{tabular}{|c|c|c|c|c|c|c|c|c|c|c|c|c|c|}
\hline $\begin{array}{l}\text { Statist } \\
\text { ic }\end{array}$ & $\begin{array}{c}\text { M } \\
\text { ale }\end{array}$ & $\begin{array}{l}\text { Fem } \\
\text { ale }\end{array}$ & $\begin{array}{c}\mathrm{Ag} \\
\text { ed } \\
18 \\
- \\
30\end{array}$ & $\begin{array}{c}\mathrm{Ag} \\
\text { ed } \\
31 \\
- \\
45\end{array}$ & $\begin{array}{c}\mathrm{Ag} \\
\text { ed } \\
46 \\
- \\
65\end{array}$ & $\begin{array}{l}\text { I work } \\
\text { in a } \\
\text { manage } \\
\text { ment } \\
\text { role }\end{array}$ & $\begin{array}{c}\text { I } \\
\text { work } \\
\text { in a } \\
\text { polic } \\
\text { y / } \\
\text { plan } \\
\text { ning } \\
\text { role }\end{array}$ & $\begin{array}{c}\text { I am } \\
\text { a } \\
\text { tech } \\
\text { nical } \\
\text { speci } \\
\text { alist } \\
\text { or } \\
\text { advis } \\
\text { er }\end{array}$ & $\begin{array}{c}\text { I am a } \\
\text { libraria } \\
n \text { or } \\
\text { inform } \\
\text { ation } \\
\text { officer }\end{array}$ & $\begin{array}{c}\text { I work } \\
\text { in a } \\
\text { Natio } \\
\text { nal } \\
\text { instit } \\
\text { ution } \\
\text { e.g. } \\
\text { govt. } \\
\text { dept. }\end{array}$ & $\begin{array}{l}\text { I work } \\
\text { for a } \\
\text { regiona } \\
\text { I or } \\
\text { interna } \\
\text { tional } \\
\text { organis } \\
\text { ation } \\
\text { e.g. } \\
\text { SPREP, } \\
\text { SPC, } \\
\text { USP, } \\
\text { FAO } \\
\text { etc. }\end{array}$ & $\begin{array}{l}\text { I am } \\
\text { a } \\
\text { Pacif } \\
\text { ic } \\
\text { Islan } \\
\text { der }\end{array}$ & $\begin{array}{l}\text { I am } \\
\text { an } \\
\text { expat } \\
\text { riate }\end{array}$ \\
\hline $\begin{array}{l}\text { Min } \\
\text { Value }\end{array}$ & 1 & 1 & 1 & 1 & 1 & 1 & 1 & 1 & 1 & 1 & 1 & 1 & 1 \\
\hline $\begin{array}{l}\text { Max } \\
\text { Value }\end{array}$ & 1 & 1 & 1 & 1 & 1 & 1 & 1 & 1 & 1 & 1 & 1 & 1 & 1 \\
\hline Mean & $\begin{array}{l}1 . \\
00\end{array}$ & 1.00 & $\begin{array}{l}1 . \\
00\end{array}$ & $\begin{array}{c}1 . \\
00\end{array}$ & $\begin{array}{l}1 . \\
00\end{array}$ & 1.00 & 1.00 & 1.00 & 1.00 & 1.00 & 1.00 & 1.00 & 1.00 \\
\hline $\begin{array}{l}\text { Varia } \\
\text { nce }\end{array}$ & $\begin{array}{l}0 . \\
00\end{array}$ & 0.00 & $\begin{array}{l}0 . \\
00\end{array}$ & $\begin{array}{l}0 . \\
00\end{array}$ & $\begin{array}{l}0 . \\
00\end{array}$ & 0.00 & 0.00 & 0.00 & 0.00 & 0.00 & 0.00 & 0.00 & 0.00 \\
\hline $\begin{array}{l}\text { Stand } \\
\text { ard } \\
\text { Devia } \\
\text { tion }\end{array}$ & $\begin{array}{c}0 . \\
00\end{array}$ & 0.00 & $\begin{array}{c}0 . \\
00\end{array}$ & $\begin{array}{c}0 . \\
00\end{array}$ & $\begin{array}{c}0 . \\
00\end{array}$ & 0.00 & 0.00 & 0.00 & 0.00 & 0.00 & 0.00 & 0.00 & 0.00 \\
\hline $\begin{array}{l}\text { Total } \\
\text { Respo } \\
\text { nses }\end{array}$ & 11 & 14 & 3 & 14 & 8 & 10 & 12 & 12 & 2 & 6 & 13 & 13 & 11 \\
\hline
\end{tabular}

\section{Where do you work?}

\begin{tabular}{|c|l|c|c|c|}
\hline$\#$ & Answer & Response & $\%$ \\
\hline 1 & NGO & 2 & $8 \%$ \\
2 & Govt. Dept. or Ministry (Pacific) & 3 & $12 \%$ \\
3 & USP & 1 & $4 \%$ \\
4 & SPC & 4 & $16 \%$ \\
5 & SOPAC & 3 & $12 \%$ \\
6 & SPREP & 3 & $12 \%$ \\
7 & Pacific Forum & 0 & $0 \%$ \\
8 & Other & 9 & $36 \%$ \\
\hline & Total & 25 & $100 \%$ \\
\hline
\end{tabular}




\section{Other}

Self Employed

Non PI Govt. dept., but based in Pacific

GIZ (German Agency for International Cooperation - on a project with SPC UNDP

Institute for Research and Social Analysis

What are these acronyms? I am a student in a PhD university

\begin{tabular}{|l|r|}
\hline Statistic & Value \\
\hline Min Value & 1 \\
Max Value & 8 \\
Mean & 5.28 \\
Variance & 6.21 \\
Standard Deviation & 2.49 \\
Total Responses & 25 \\
\hline
\end{tabular}

